\title{
IMPACTOS DAS BARREIRAS COMERCIAIS DOS ESTADOS UNIDOS E UNIÃO EUROPÉIA SOBRE A PAUTA DE EXPORTAÇÕES AGRÍCOLAS BRASILEIRAS
}

ISABEL FERNANDES PINTO VIEGAS

Dissertação apresentada à Escola Superior de Agricultura "Luiz de Queiroz", Universidade de São Paulo, para obtenção do título em Mestre em Agronomia, Área de Concentração: Economia Aplicada.

P I R A C I C A B A

Estado de São Paulo - Brasil

Agosto - 2003 


\title{
IMPACTOS DAS BARREIRAS COMERCIAIS DOS ESTADOS UNIDOS E UNIÃO EUROPÉIA SOBRE A PAUTA DE EXPORTAÇÕES AGRÍCOLAS BRASILEIRAS
}

\author{
ISABEL FERNANDES PINTO VIEGAS \\ Engenheiro Agrônomo
}

Orientador: Prof. Dr. MARCOS SAWAYA JANK

\begin{abstract}
Dissertação apresentada à Escola Superior de Agricultura "Luiz de Queiroz", Universidade de São Paulo, para obtenção do título em Mestre em Agronomia, Área de Concentração: Economia Aplicada.
\end{abstract}

P I R A C I C A B A

Estado de São Paulo - Brasil

Agosto - 2003 
Dados Internacionais de Catalogação na Publicação (CIP) DIVISÃO DE BIBLIOTECA E DOCUMENTAÇÃO - ESALQ/USP

\author{
Viegas, Isabel Femandes Pinto \\ Impac tos das ba reiras comerc ia is dos Esta dos Unidose União Européia \\ sobre a pauta de exportaçõesagńc olas brasileiras/ Isabel FemandesPinto \\ Viegas. - - Piracicaba, 2003. \\ $68 \mathrm{p}$. \\ Dissertação (mestrado) - - Escola Superior de Agricultura Luiz de Queiroz, \\ 2003. \\ Bibliografia. \\ 1. Economia intemacional 2. Exportação 3 . Integração econômica 4 \\ Política comercial 6. Polític a tarifária 7. Produtos a gríc olas I. Título
}

CDD 338.14 
A meus pais, Flávio e Josita. 


\section{AGRADECIMENTOS}

Agradeço a todos que colaboraram direta ou indiretamente para a realização desse trabalho.

Ao meu orientador, Marcos Sawaya Jank que com sua dedicação me despertou o interesse por economia e que, mesmo distante, me apoiou e incentivou.

À Sílvia Miranda, que supriu essa distância e foi fundamental para a realização desse trabalho, não somente por sua orientação, mas também pela amizade e apoio.

Aos professores Alexandre Mendonça de Barros, Heloísa Lee Burnquist e Márcia Azanha que participaram de várias etapas colaborando imensamente com esse trabalho.

Ao professor Evaristo Marzabal Neves que me acolheu e acreditou no meu potencial.

À CAPES pelo apoio financeiro.

Aos funcionários do departamento, principalmente à Maielli pela dedicação e carinho com que trata todos os alunos. À Ligiana pelo auxílio na normatização do trabalho.

Ao meu irmão, Du e aos meus avós, que tanto me incentivaram e inspiraram durante toda a minha vida.

Aos meus tios Klaus e Ceres que me recepcionaram com tanto carinho na minha chegada à Piracicaba.

Aos meus amigos e colegas que colaboraram diretamente com esse trabalho: Clea, Roberta Castro, Alex, Roberta Marques, Chucky, Clarissa, Vítor, Bruna, Rogério e Joaquim. Aos meus outros amigos, tão queridos, que são tão importantes na minha vida. 


\section{SUMÁRIO}

Página

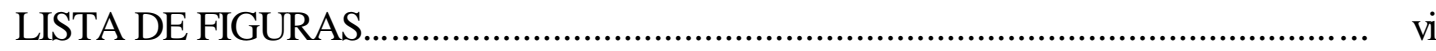

LISTA DE QUADROS....................................................................................... vii

LISTA DE TABELAS............................................................................................. viii

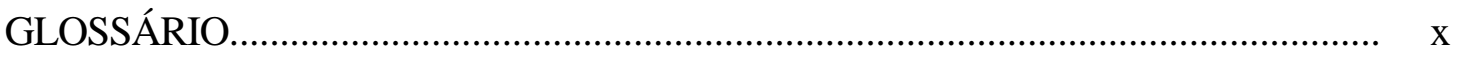

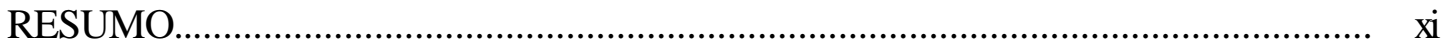

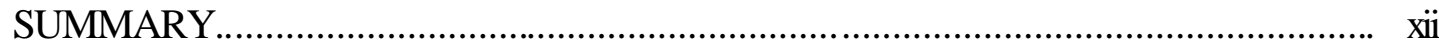

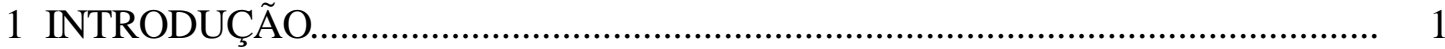

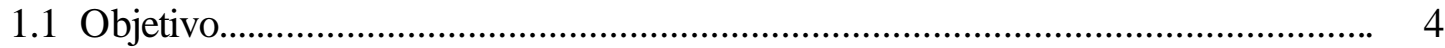

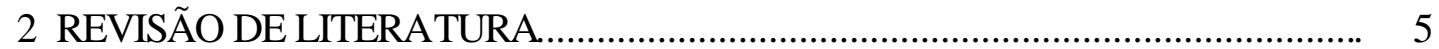

2.1 Histórico das barreiras................................................................................... 5

2.2 Definições dos principais tipos de barreiras....................................................... 8

2.3 Efeitos das barreiras sobre o comércio................................................................... 13

2.3.1 Estudos que avaliaram a importância das barreiras.......................................... 20

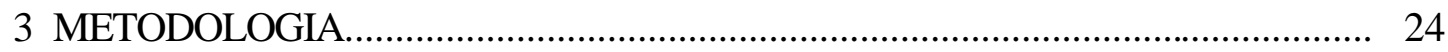

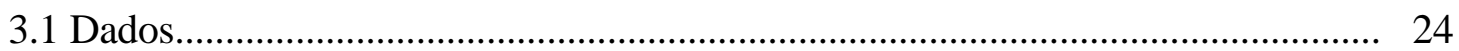

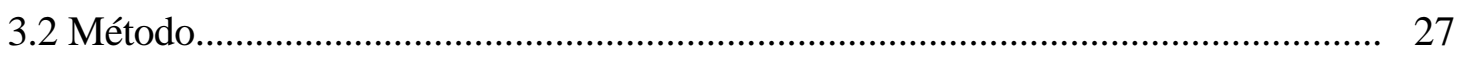

4 RESULTADOS E DISCUSSÃO.................................................................... 33

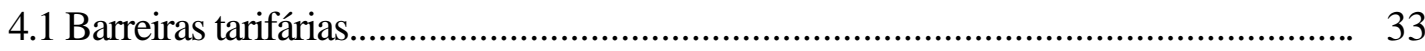

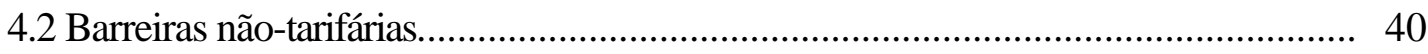

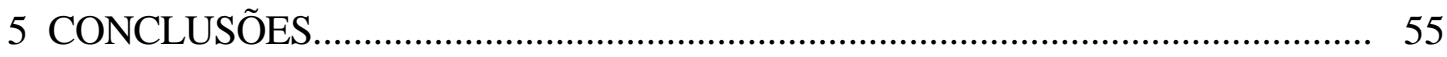

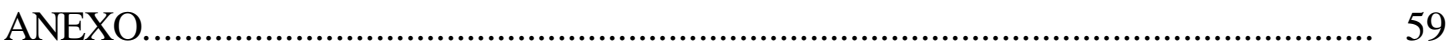

REFERÊNCIAS BIBLIOGRÁFICAS............................................................... 62

APÊNDICE 


\section{LISTA DE FIGURAS}

Página

1 Diferença entre negociações das tarifas consolidada e aplicada................................ 10

2 Representação gráfica das tarifas específica e ad valorem com relação ao preço..... 13

3 Efeitos da aplicação de tarifas em um país importador grande................................ 14

4 Efeito da imposição de uma tarifa em um país pequeno ............................................ 15

5 Efeitos do uso de quotas tarifárias nas importações.................................................. 17 


\section{LISTA DE QUADROS}

Página

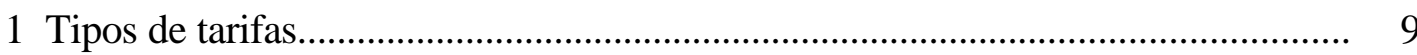

2 Possíveis efeitos de alterações nas políticas de quotas tarifárias sobre importações............................................................................................. 18

3 Relação entre índice de frequiência e índice de cobertura........................................ 31

4 Relação entre média e mediana......................................................................... 32

5 Principais produtos afetados, em termos de valor exportado pelo Brasil, por barreiras não-tarifárias, nos Estados Unidos..................................................... 45

6 Principais produtos afetados, em termos de valor exportado pelo Brasil, por barreiras não-tarifárias, na União Européia em 2000......................................... 48 


\section{LISTA DE TABELAS}

1 Índices de frequiência e cobertura de picos tarifários sobre

Página as exportações agrícolas brasileiras para Estados Unidos e

União Européia, em 2000

2 Estatísticas das tarifas dos Estados Unidos para produtos agrícolas em 2000

3 Estrutura tarifária dos Estados Unidos para produtos agrícolas em 2000 expressa em \% do valor.

4 Índices de frequiência e cobertura para picos tarifários sobre as exportações agrícolas brasileiras para os Estados Unidos em 2000, considerando os capítulos segundo o sistema harmonizado

5 Estatísticas das tarifas para produtos agrícolas da União Européia em 2000

6 Estrutura tarifária da União Européia para produtos agrícolas em 2000 expressa em \% do valor.

7 Índices de freqüência e de cobertura para picos tarifários sobre as exportações agrícolas brasileiras para União Européia em 2000, considerando os capítulos segundo o sistema harmonizado.

8 Porcentagem da pauta de exportações agrícolas brasileiras sujeitas a algum tipo de barreira não-tarifária nos Estados Unidos e União Européia em 2000, expressa em \% do valor (US\$ FOB) 
9 Índice de cobertura e índice de frequiência para quotas tarifárias sobre as exportações agrícolas brasileiras para os Estados Unidos e União Européia em 2000.

10 Índice de freqüência e índice de cobertura para os diferentes tipos de BNTs sobre as exportações agrícolas brasileiras, impostas pelos Estados Unidos em 2000..

11 Índice de frequiência e índice de cobertura para as BNTs sobre as exportações agrícolas brasileiras impostas pela União Européia em 2000.

12 Índice de frequiência e índice de cobertura para barreiras não-tarifárias sobre as exportações agrícolas brasileiras impostas pelos Estados Unidos em 2000, por capítulo, segundo o sistema harmonizado.

13 Índice de frequiência e índice de cobertura para barreiras não-tarifárias sobre as exportações agrícolas brasileiras impostas pela União Européia em 2000, por capítulo segundo o sistema harmonizado..

14 Presença de picos tarifários e barreiras não-tarifárias sobre as exportações agrícolas brasileiras, por capítulos, nos Estados Unidos e União Européia em 2000. 


\section{GLOSSÁRIO}

ALCA - Área de Livre Comércio das Américas

AMAD - Agricultural Market Access Database

BDH - Base de Dados Hemisférica da ALCA

BNT - Barreira Não-Tarifária

EUA - Estados Unidos da América

FAO - Food and Agriculture Organization

GATT - Acordo Geral de Tarifas e Comércio

IC - Índice de Cobertura

IF - Índice de Frequiência

MFN - Nação Mais Favorecida

NCM - Nomenclatura Comum do Mercosul

OMC - Organização Mundial de Comércio

SH - Sistema Harmonizado

SPS - Barreiras Sanitárias e Fitossanitárias

TBT - Barreiras Técnicas

TRAINS - Trade Analysis and Information System

UE - União Européia 


\title{
IMPACTOS DAS BARREIRAS COMERCIAIS DOS ESTADOS UNIDOS E UNIÃO EUROPÉIA SOBRE A PAUTA DE EXPORTAÇÕES AGRÍCOLAS BRASILEIRAS
}

\author{
Autora: ISABEL FERNANDES PINTO VIEGAS \\ Orientador: Prof. Dr. MARCOS SAWAYA JANK
}

\section{RESUMO}

O Brasil possui um grande potencial agrícola e deve ampliar suas exportações para reduzir o déficit em transações correntes. No entanto, as exportações agrícolas brasileiras estão sujeitas a restrições tarifárias e não-tarifárias nos Estados Unidos e na União Européia, mercados importantes para o Brasil. Este trabalho visou a avaliar a incidência de picos tarifários, quotas tarifárias, barreiras técnicas e barreiras sanitárias e fitossanitárias sobre o valor das exportações agrícolas brasileiras nos Estados Unidos e na União Européia, definir as medidas de proteção mais usadas por cada um desses parceiros comerciais e verificar os principais produtos e complexos agrícolas sujeitos a essas medidas no ano 2000, através da utilização dos índices de cobertura e frequiência. 


\section{IMPACTS OF TRADE BARRIERS IMPOSED BY UNITED STATES AND EUROPEAN UNION ON BRAZILIAN AGRICULTURAL EXPORTS}

Author: ISABEL FERNANDES PINTO VIEGAS Adviser: Prof. Dr. MARCOS SAWAYA JANK

\section{SUMMARY}

Brazil has a large agricultural potential and must increase its exports to reduce the deficit in current transactions. However, Brazilian agricultural exports are subject to tariff and non-tariff trade restrictions in the United States and European Union, which are important markets for Brazil. The purpose of this theses was to evaluate the importance of tariff peaks, tariff rate quotas, technical barriers, sanitary and phytosanitary measures over Brazilian agricultural export value in the United States and European Union, to define the protection measures applied by each of these trade partners and verify which are the main agricultural products subjects to these measures in the year 2000, by the use of frequency and coverage indexes. 


\section{INTRODUÇÃO}

O Brasil é um país com boa dotação de recursos naturais e humanos e por isso mesmo com um grande potencial agrícola, sendo que o agronegócio corresponde a cerca de $40 \%$ do total das exportações e a $27 \%$ do PIB. No entanto, o valor exportado pelo país é muito pequeno e deve ser ampliado de forma a reduzir o atual déficit nas transações correntes, diminuindo assim a necessidade de investimento externo.

A inserção do Brasil nos blocos regionais de comércio, como $\operatorname{ALCA}^{1}$ e UEMercosul $^{2}$, se for feita de forma coerente e voltada também para os produtos agropecuários e agroindustriais que apresentam grande competitividade, pode resultar no aumento das exportações em função de um melhor acesso aos mercados dos países membros. O Brasil é competitivo em vários segmentos da agricultura como na soja, suco de laranja, açúcar, carne de frango e produtos pecuários. No entanto, essa inserção no mercado internacional ainda está sujeita a uma série de barreiras.

Por parte do Brasil, a alta incidência de impostos e taxas, infra-estrutura precária (transporte, prtos, etc.), as altas taxas de juros - dentro do que se convencionou chamar de custo Brasil - são fatores por demais conhecidos e analisados, que diminuem a competitividade dos produtos brasileiros no mercado externo.

\footnotetext{
1 Área de Livre Comércio das Américas (ALCA) é um processo iniciado em Miami em 1994, que visa a integrar as economias das Américas em uma área de livre comércio. Dela fazem parte 34 países das Américas.

2 O Mercosul e a União Européia assinaram em 1995 o "Acordo Quadro Inter-Regional de Cooperação", instrumento de transição para uma futura associação inter-regional, cujo pilar básico seria a implementação de um programa de liberalizarão progressiva dos fluxos comerciais recíprocos (Mercosul, 2003).
} 
Por outro lado, as exportações brasileiras são limitadas por consideráveis restrições ao comércio nos mercados internacionais, principalmente nos países da União Européia e Estados Unidos, na forma de barreiras tarifárias e não-tarifárias. Além disso, grande parte dos países desenvolvidos costuma subsidiar fortemente os seus agricultores, provocando a formação de excedentes que são escoados no mercado internacional por meio de subsídios diretos, instrumentos de apoio de crédito e mecanismos de ajuda alimentar.

Nos últimos 10 anos, as exportações brasileiras para os Estados Unidos diminuíram, devido principalmente à presença de picos tarifários, quotas tarifárias e medidas sanitárias e fitossanitárias. Estima-se que essas barreiras afetaram aproximadamente $50 \%$ da agricultura brasileira e das exportações do agronegócio para os Estados Unidos.

As barreiras tarifárias são restrições impostas pelos governos mediante tarifas aduaneiras ou impostos de importação. As barreiras não-tarifárias (BNTs) são restrições de quantidades, composição e destino de produtos no comércio internacional, podendo ser citadas as quotas, os contingenciamentos, as licenças de importação, as medidas sanitárias e fitossanitárias, entre outras. Tanto as barreiras tarifárias como as nãotarifárias são mais facilmente negociáveis em acordos bilaterais, enquanto os subsídios (domésticos e à exportação) e uso abusivo de legislação antidumping são mais facilmente negociáveis na esfera multilateral.

O Brasil concentra sua produção em commodities agrícolas, que geralmente são produtos padronizados, que apresentam economias de escala, o que permite volumes crescentes de comércio. Alguns exemplos de commodities são açúcar, soja, suco de laranja. Contudo, também tem expandido a produção de especialidades, que, por sua vez, são produtos diferenciados, de maior valor adicionado, que necessitam de mais investimentos, mas podem trazer maiores margens sobre as exportações.

Com o crescente processo de integração econômica, é necessário que os países concentrem a sua produção em bens que apresentem vantagens comparativas e que reduzam a produção daqueles bens que deverão perder competitividade no mercado mundial. O Brasil, além de levar em consideração suas vantagens comparativas, deve 
estudar as características de cada um desses blocos, suas necessidades, vocações, sua política e posicionar-se de forma a obter ganhos com essas relações e evitar grandes prejuízos aos setores nacionais.

$\mathrm{O}$ atual processo de negociações para o estabelecimento de novos blocos econômicos e as negociações comerciais com blocos já estabelecidos torna necessário um maior estudo das medidas protecionistas adotadas por esses blocos e seus impactos sobre as exportações mundiais. As Rodadas do GATT/OMC são exemplos de fórum, nos quais são essenciais as informações a respeito do protecionismo e seus efeitos sobre o comércio, informações ainda escassas em muitos países, principalmente nos países em desenvolvimento.

Diversos estudos têm indicado que as medidas protecionistas, aqui compreendidas barreiras comerciais, adotadas por países e blocos para proteger a sua agricultura, provocam distorções no comércio mundial, afetando, assim, as exportações dos países. Isso porque grande parte desses países tem suas economias dependentes do comércio de produtos do agronegócio, os quais têm sido altamente protegidos. Esses efeitos sobre as exportações podem ser analisados pela observação da composição e porcentagem da pauta que é afetada por barreiras tarifárias e não-tarifárias. 


\subsection{Objetivo}

O objetivo deste trabalho é avaliar a importância dss barreiras comerciais sobre o valor das exportações agrícolas brasileiras, considerando a porcentagem da pauta que está sujeita a essas barreiras.

Para tanto, será estimada a parcela dessas exportações que é afetada por picos tarifários, quotas tarifárias, barreiras sanitárias e fitossanitárias e barreiras técnicas impostos pelos Estados Unidos e pela União Européia no ano de 2000.

Serão também destacados os principais produtos pertencentes à pauta de exportações do Brasil que são afetados pelas barreiras em questão. 


\section{REVISÃO DE LITERATURA}

\subsection{Histórico das barreiras}

O protecionismo acentuou-se principalmente no período entre as guerras mundiais. Os Estados Unidos, que, após a Primeira Guerra, emergiram como potência, aumentaram bruscamente suas tarifas aduaneiras, levando seus parceiros comerciais a impor retaliações. A prática do protecionismo disseminourse rapidamente através de uma série de restrições ao comércio (Carvalho \& Silva, 2000).

Com o avanço das exportações dos novos países industrializados, durante a recessão dos países desenvolvidos na década de 70, ocorreu o crescimento da proteção à produção nacional das economias avançadas. Após as rodadas do GATT, foram impostas regras para redução das tarifas alfandegárias. Isso fez com que os países desenvolvidos buscassem novas formas de proteção: as barreiras não-tarifárias, que não eram regulamentadas. Essas barreiras não-tarifárias prejudicam principalmente os setores ditos tradicionais, nos quais os países em desenvolvimento são competitivos. Tendem a ter efeitos mais perversos, devido à falta de transparência e à arbitrariedade de sua aplicação (Castilho,1996).

O protecionismo do mercado agrícola internacional teve um aumento significativo na década de 80, quando os preços e as exportações agrícolas decresceram, levando ao aumento dos subsídios às exportações e barreiras às importações agrícolas provenientes de países em desenvolvimento (Fagundes, 1994).

Segundo Thorstensen (1999), até então, o comércio de produtos agrícolas encontrava-se à margem das regras do GATT e era submetido a altos níveis de subsídios domésticos e à exportação. Os EUA e a UE, a fim de proteger o seu mercado das 
importações, subsidiavam fortemente suas agriculturas;além disso, existia uma forte pressão política dos agricultores dos países desenvolvidos, fatores que dificultaram a entrada desse tema nas regras do GATT.

Nessa mesma década, houve um acréscimo da participação dos países em desenvolvimento nas exportações agrícolas mundiais, aumentando a concorrência com os países desenvolvidos que dominavam esse mercado. A principal política adotada pelos países desenvolvidos foi a de elevar os preços internos desses produtos, gerando um aumento da oferta superior à demanda mundial, dificuldades de exportação e acúmulo de estoques. Nesse cenário, houve a necessidade de se regulamentarem as políticas ligadas ao setor agrícola, introduzindo-se esse assunto nas negociações multilaterais da OMC na Rodada Uruguai (Fagundes, 1994).

A Rodada Uruguai foi a oitava rodada do GATT, na qual se integraram às regras temas antes excluídos, entre os quais a agricultura. Essa rodada deu origem à $\mathrm{OMC}$ em 1995.

O Brasil participa do Grupo de Cairns $^{3}$, que tem como objetivo obter maior liberalização do setor agrícola por meio de maior acesso aos mercados, redução dos subsídios domésticos e às exportações, conflitando, principalmente, com os interesses da UE, Suíça, Japão e Coréia.

Segundo Jank \& Nassar (2000), o Acordo Agrícola da Rodada Uruguai prevê a regularização dos níveis de subsídios e protecionismo do setor agrícola. Foi elaborado com base na necessidade de maior transparência desses mercados, liberalização gradual do comércio através da redução de barreiras, correção nas distorções de preços e equilíbrio nas condições de concorrência através da redução de subsídios.

O Acordo da Rodada Uruguai, além de ter introduzido a agricultura nas normas e disciplinas do GATT, apresentou, como resultados, redução dos subsídios às exportações, redução do apoio doméstico aos produtores, conversão das barreiras não-

\footnotetext{
${ }^{3}$ Grupo formado em 1986 que se reuniu pela primeira vez na cidade de Cairns (Austrália) e que tem como objetivo influir a favor da liberalização dos mercados agropecuários. È constituído por 17 países que têm sua economia voltada principalmente para os agronegócios e que, isoladamente, não teriam maiores condições de influir no processo negociador (Jank \& Viegas, 1999).
} 
tarifárias em tarifas equivalentes (tarificação), consolidação e redução de todas as tarifas, acesso a quotas mínimas para produtos que estavam bloqueados através de proibições (Thorstensen, 1999).

Segundo Castilho (2000), o acordo agrícola preservou um alto nível de proteção nos países industrializados conferindo uma larga margem de redução das tarifas, já que os níveis tarifários consolidados foram muito altos.

As expectativas de eliminação total dos subsídios não foram concretizadas, sendo que o Brasil continua importando produtos subsidiados e exportando para mercados protegidos.

Segundo Pinazza \& Alimandro (2001), quanto ao acesso a mercados, ao contrário do que se esperava, o uso de barreiras intensificou-se após a Rodada Uruguai. A tarificação apenas transformou barreiras não-tarifárias em tarifárias, não repercutindo muito na promoção do comércio de produtos agrícolas.

Ainda segundo Thorstensen (1999), o Acordo Agrícola acabou legalizando as políticas protecionistas e subsidiadas dos países desenvolvidos, principalmente EUA e UE.

Os países em desenvolvimento, em particular, são potencialmente grandes exportadores de produtos agrícolas e perdem muito com as restrições impostas ao comércio desses produtos (DeGorter, 2001). 


\subsection{Definições dos principais tipos de barreiras}

O Acordo Agrícola da Rodada Uruguai prevê o estabelecimento de regras mais transparentes para o tratamento de barreiras, sendo negociado em 3 áreas:

1- Acesso a Mercados

2- Medidas de Apoio Doméstico

3- Subsídios àExportação

As principais conquistas nesse acordo foram:

- Tarificação, ou seja, transformação de barreiras não tarifárias em tarifas equivalentes.

- Redução do nível de apoio doméstico na "caixa amarela",.

- Redução nos subsídios às exportações e no volume e valor subsidiados.

As negociações para a área de acesso a mercados em acordos multilaterais englobam barreiras tarifárias e barreiras não-tarifárias.

Entre as barreiras não-tarifárias tem-se verificado uma crescente importância das medidas sanitárias e fitossanitárias. Essas medidas acabam tornando-se barreiras, uma vez que impedem o acesso de determinados produtos aos mercados que as impõem.

As medidas sanitárias e fitossanitárias estabelecem padrões de exigência na determinação de regras sobre produção, processamento e consumo de produtos alimentares. Podem converter-se em proibições para países exportadores dos produtos sujeitos a essas medidas, muitas vezes objetivando proteger o setor produtivo doméstico (Thorstensen, 1999).

As quotas tarifárias são definidas como quantidades com tarifas reduzidas que visam a garantir um nível mínimo de acesso a mercado na pauta de importação dos países e acima do volume estabelecido na quota, os produtos ficam sujeitos a tarifas

\footnotetext{
${ }^{4}$ O Acordo Agrícola da OMC classifica as políticas de apoio interno em "caixas" de acordo com seu efeito no mercado. A "caixa amarela" refere-se a políticas que provocam distorções no comércio internacional (políticas de preços mínimos, políticas de crédito subsidiado, entre outras). A "caixa azıl" refere-se a políticas permitidas de compensação à redução de preços vinculadas ao controle de produção (congelamento de terras). A "caixa verde" refere-se a medidas de apoio interno definidas como subsídios permitidos pela OMC (Jank \& Viegas, 1999).
} 
maiores. Surgiram após o processo de tarificação que, por sua vez, provocou a ocorrência de picos tarifários, impedindo o acesso a mercados de quantidades acima da quota estabelecida (Thorstensen, 1999).

Durante a Rodada Uruguai, foram assumidos compromissos de acesso mínimo através da utilização do mecanismo de quotas tarifárias.

O acesso mínimo refere-se ao uso de tarifas baixas (intra quota) para quantidades estabelecidas nas quotas e tarifas elevadas (extra quota) para quantidades que excedem a quota. Corresponde a 3\% do consumo doméstico, tomando como base o período de 1986 a 1988, e com aumento para 5\% no ano 2000 (2004 para países em desenvolvimento) (DeGorter,2001).

\begin{tabular}{|c|c|c|c|}
\hline \multicolumn{3}{|c|}{ Tarifas } & Descrição \\
\hline $\begin{array}{l}\text { Tarifa } \\
\text { Tariff) }\end{array}$ & Consolidada & (Bound & $\begin{array}{l}\text { É uma tarifa fixada como limite máximo ou teto } \\
\text { tarifário (ceiling binding) dentro de uma } \\
\text { negociação comercial, de tal forma que uma tarifa } \\
\text { aplicada não pode ultrapassá-la. Foram } \\
\text { consolidadas diversas tarifas durante o processo de } \\
\text { tarificação da Rodada Uruguai. }\end{array}$ \\
\hline Tarifa & licada & & $\begin{array}{l}\text { É a taxa efetivamente imposta sobre as } \\
\text { importações. Pode ser inferior à tarifa consolidada } \\
\text { na OMC, porém não pode excedê-la, conforme } \\
\text { acordado na Rodada Uruguai. }\end{array}$ \\
\hline
\end{tabular}

Quadro 1 - Tipos de tarifas.

Fonte: Elaborado pela autora.

No acordo da OMC obedece-se ao princípio da Nação Mais Favorecida (MFN), no qual se estabelece que os mesmos privilégios comerciais concedidos por um país a outro devem ser estendidos aos demais membros da OMC. Muitos países aplicam, sobre 
as importações de bens, a tarifa aplicada, que é substancialmente mais baixa que a tarifa consolidada na OMC e é da tarifa aplicada que se devem negociar reduções para garantir maior acesso a mercado (Laird, 1998). Mesmo após as reduções tarifárias ocorridas após a Rodada Uruguai, algumas tarifas consolidadas permaneceram extremamente elevadas.

Segundo a figura 1 , se as negociações forem realizadas no sentido de se diminuir as tarifas consolidadas, do ano 0 até o ano m não se observará nenhum efeito, já que a tarifa que está vigorando é a tarifa aplicada. Entretanto após o ano m, a redução tarifária será muito brusca, podendo prejudicar a indústria doméstica, que terá menos tempo para se adaptar a essa redução. No caso de se negociar a tarifa aplicada, a redução será mais gradual.

$\mathrm{Na} \mathrm{OMC}$, as negociações com relação à redução tarifária são baseadas nas tarifas consolidadas, que ficarão estabelecidas em níveis acima de zero. Nos acordos regionais, como é o caso da ALCA, a negociação é feita com base na tarifa aplicada; essa tarifa poderá chegar a zero em algumas linhas tarifárias.

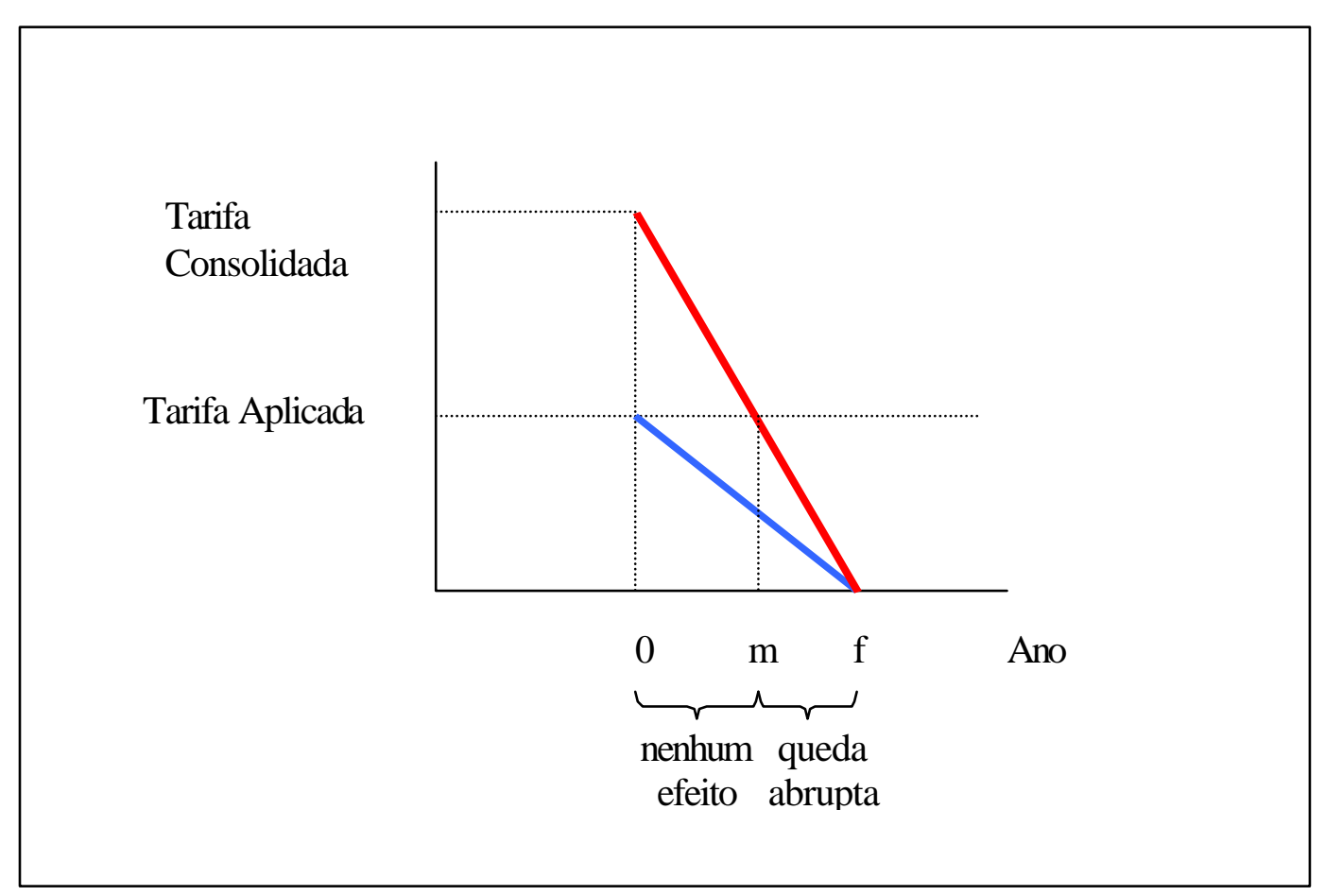

Figura 1 - Diferença entre negociações das tarifas consolidada e aplicada.

Fonte: Elaborado pela autora. 
Outro fator que favoreceu o aparecimento de tarifas extremamente elevadas foi o processo de tarificação. A tarificação foi determinada no Acordo Agrícola da Rodada Uruguai e prevê a eliminação ou conversão de todas as barreiras não-tarifárias em equivalentes tarifários (Jank \& Viegas, 1999).

Segundo Jank et al. $(2001)^{5}$, teoricamente, uma tarifa é considerada um pico tarifário quando é capaz de impedir o comércio de um bem ao qual ela se aplica. $\mathrm{Na}$ prática, essa definição encontra algumas limitações:

- a proteção a alguns produtos não se dá apenas na forma de tarifas, mas também na forma de quotas tarifárias;

- alguns picos tarifários não conseguem impedir por completo as importações, pois a indústria doméstica não consegue suprir a demanda;

- a necessidade de se definirem picos tarifários através de cortes tarifários necessita de generalização, o que pode levar a interpretações erradas do que seria um pico tarifário.

Segundo a OMC (2002), os picos tarifários incidem sobre poucos produtos considerados sensíveis e são usados para proteger os produtores domésticos, sendo que alguns afetam as exportações dos países em desenvolvimento.

Não há um critério universal para definir picos tarifários.Os critérios variam de acordo com cada organização e, dentre eles, os mais comuns são:

a. Tarifas acima de $12 \%$ a 6 dígitos do $\mathrm{SH}^{6}$ para todos os produtos (UNCTAD/WTO, 2000).

b. Tarifas acima de $15 \%$ a 6 dígitos do $\mathrm{SH}$ para todos os produtos (OMC, 2002).

c. Tarifas acima de $20 \%$ a 6 dígitos do $\mathrm{SH}$ para produtos agrícolas (FAO, 2002)

\footnotetext{
5 JANK, M. S. A Política Agrícola dos Estados Unidos e seu impacto nas negociações internacionais. Washington, 2001. 2p. (Relatório Técnico Final, Projeto Banco Interamericano de Desenvolvimento e Ministério das Relações Exteriores)

${ }^{6}$ Sistema Harmonizado de Designação e de Codificação de Mercadorias (SH) é um sỉtema internacional de classificação de mercadorias que classifica os produtos em até 6 dígitos e é utilizado pela maioria dos países, tornando a classificação dos produtos uniforme entre os países que adotam esse sistema.
} 
d. Tarifas acima de $100 \%$ a 6 dígitos do $\mathrm{SH}$ para produtos do agronegócio (Gibson et al., 2001).

e. Tarifas superiores a 3 vezes a tarifa média do país: tende a ser um critério mais justo por levar em consideração a estrutura tarifária do país (Laird, 1998).

f. Tarifas superiores à soma da média e um desvio padrão: é uma adaptação do critério anterior, com fácil sustentação científica (Jank et al., 2001).

g. O grupo das $1 \%$ maiores tarifas de qualquer país: tende a estabelecer um número homogêneo de tarifas por país, entretanto sua maior limitação é que em casos de países com tarifas elevadas, há uma subestimação dos picos tarifários, pois o corte ocorre em uma tarifa ainda elevada (Jank et al., 2001).

A maior limitação dos 4 primeiros critérios é que não levam em consideração a estrutura tarifária dos países em questão, não considerando a distribuição e freqüência das tarifas. São critérios pouco sustentáveis em um ambiente de negociações, porém comumente utilizados em estudos internacionais (Jank et al., 2001). 


\subsection{Efeitos das barreiras sobre o comércio}

As barreiras tarifárias são tarifas ou taxas cobradas, quando um bem é importado por um país. Essas tarifas são ditas específicas, quando um valor fixo é cobrado por unidade do bem importado, ad valorem, quando são cobradas como uma fração do bem importado e mistas, quando ocorrem as duas coisas ao mesmo tempo. Em todos os casos, o efeito dessas tarifas é aumentar o custo dos bens importados por esse país (Krugman \& Obstfeld, 1999).

O uso da tarifa específica fornece, geralmente, maior proteção nominal que a proporcionada pela tarifa ad valorem, visto que a proteção tarifária cresce, à medida que o preço do produto se reduz. Com isto, os produtores estrangeiros mais competitivos são relativamente mais prejudicados pela imposição da tarifa específica. (MDIC,1999). Conforme a figura 2, nota-se que a tarifa ad valorem acompanha a variação de preços, sendo que a razão entre essas duas variáveis é sempre constante. A tarifa específica é fixa e tem maior influência quando os preços estão baixos, pois nesses casos, representa uma parcela maior do valor do produto.

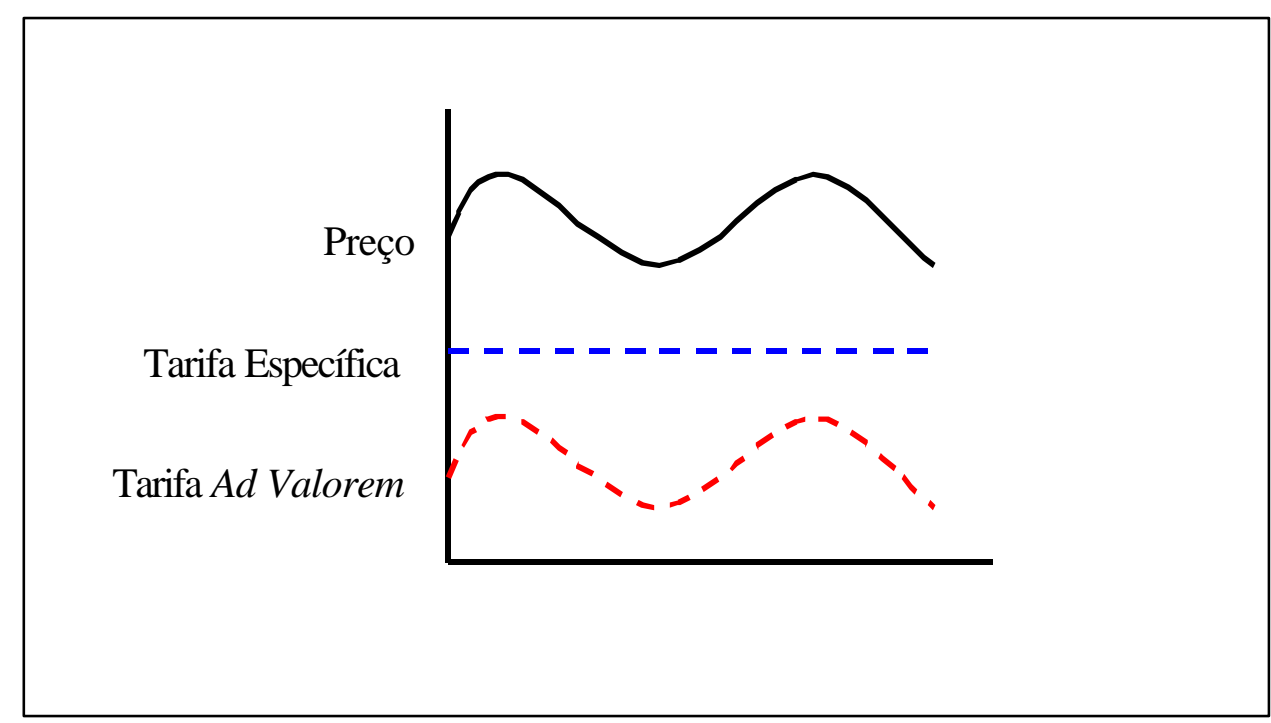

Figura 2 - Representação gráfica das tarifas específica e ad valorem com relação ao preço.

Fonte: Elaborado pela autora. 
A figura 3 ilustra o efeito, em um país grande, da aplicação de uma tarifa. Conforme essa figura, a aplicação de tarifas no mercado doméstico em relação ao mercado estrangeiro faz com que os preços se elevem nesse mercado de $\mathrm{P}_{\mathrm{I}}$ para $\mathrm{P}_{\mathrm{T}}$ e com que diminuam no mercado estrangeiro de $\mathrm{P}_{\mathrm{I}}$ para $\mathrm{P}_{\mathrm{T}} *\left(\mathrm{P}_{\mathrm{T}} *=\mathrm{P}_{\mathrm{T}}-\mathrm{t}\right)$. No mercado doméstico, os efeitos são de aumento da oferta e redução da demanda, de modo que as importações do produto em questão diminuem nesse país (deslocando de 1 para 2). No mercado estrangeiro, a redução do preço faz com que a quantidade demandada aumente e com que a quantidade ofertada do produto diminua, reduzindo-se as exportações (deslocando de 1 para 3). Isso faz com que o volume do produto comercializado diminua de $\mathrm{Q}_{\mathrm{i}}$ para $\mathrm{Q}_{\mathrm{T}}$, que é o volume comercializado na presença de uma tarifa.

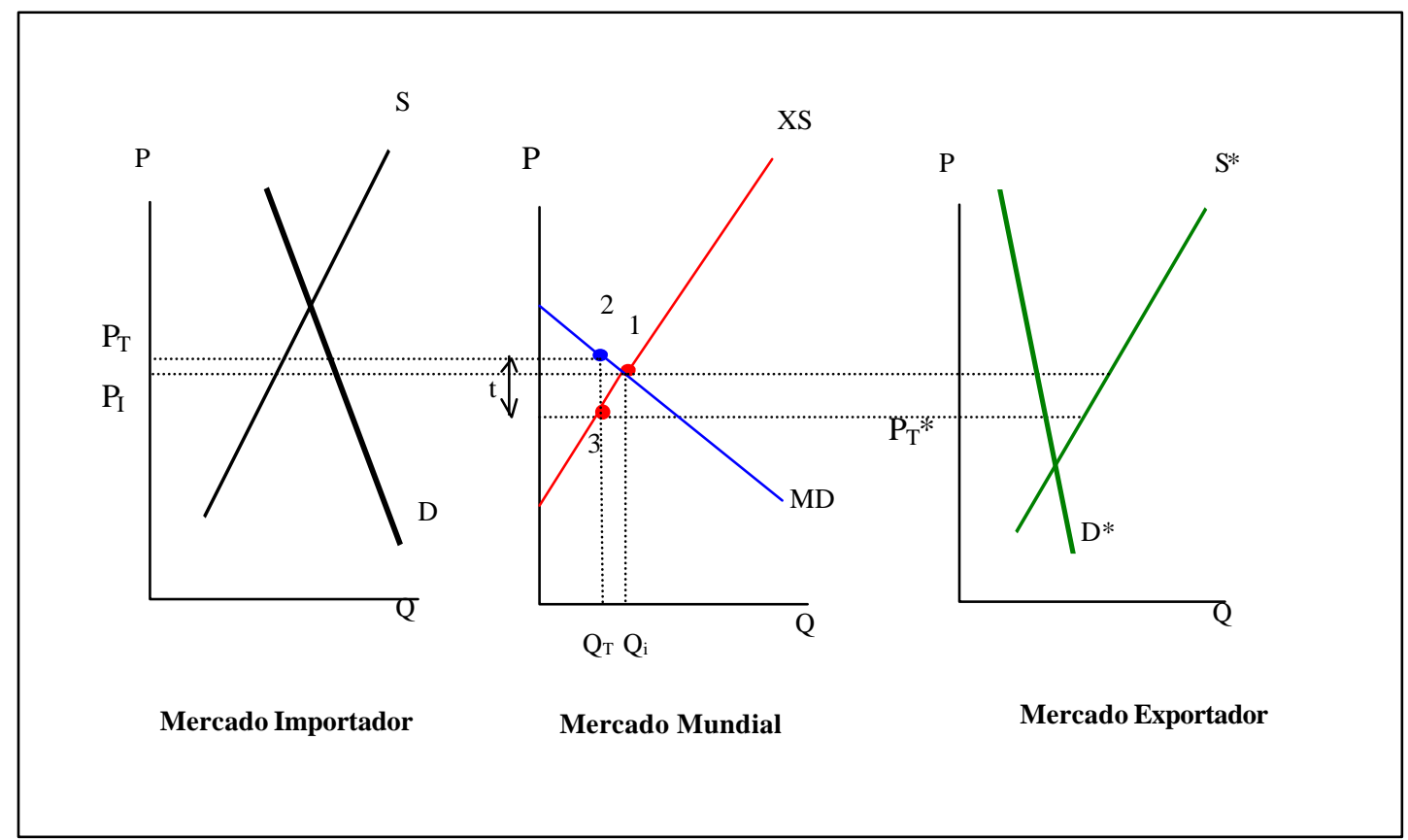

Figura 3 - Efeitos da aplicação de tarifas em um país importador grande.

Fonte: Krugman \& Obstfeld (1999)

Em um país pequeno, o principal efeito da aplicação de tarifas é o de proteger os produtores desse país, não tendo influência sobre os preços internacionais. Nesse caso, o preço do produto sobre o qual incide a tarifa, aumenta de $\mathrm{P}$ para $\mathrm{P}+\mathrm{t}$, sua demanda diminui de $\mathrm{D}^{1}$ para $\mathrm{D}^{2}$ e a produção do bem importado aumenta de $S^{1}$ para $S^{2}$. Com a 
adoção dessa medida ocorre a diminuição das importações desse país conforme a figura 4.

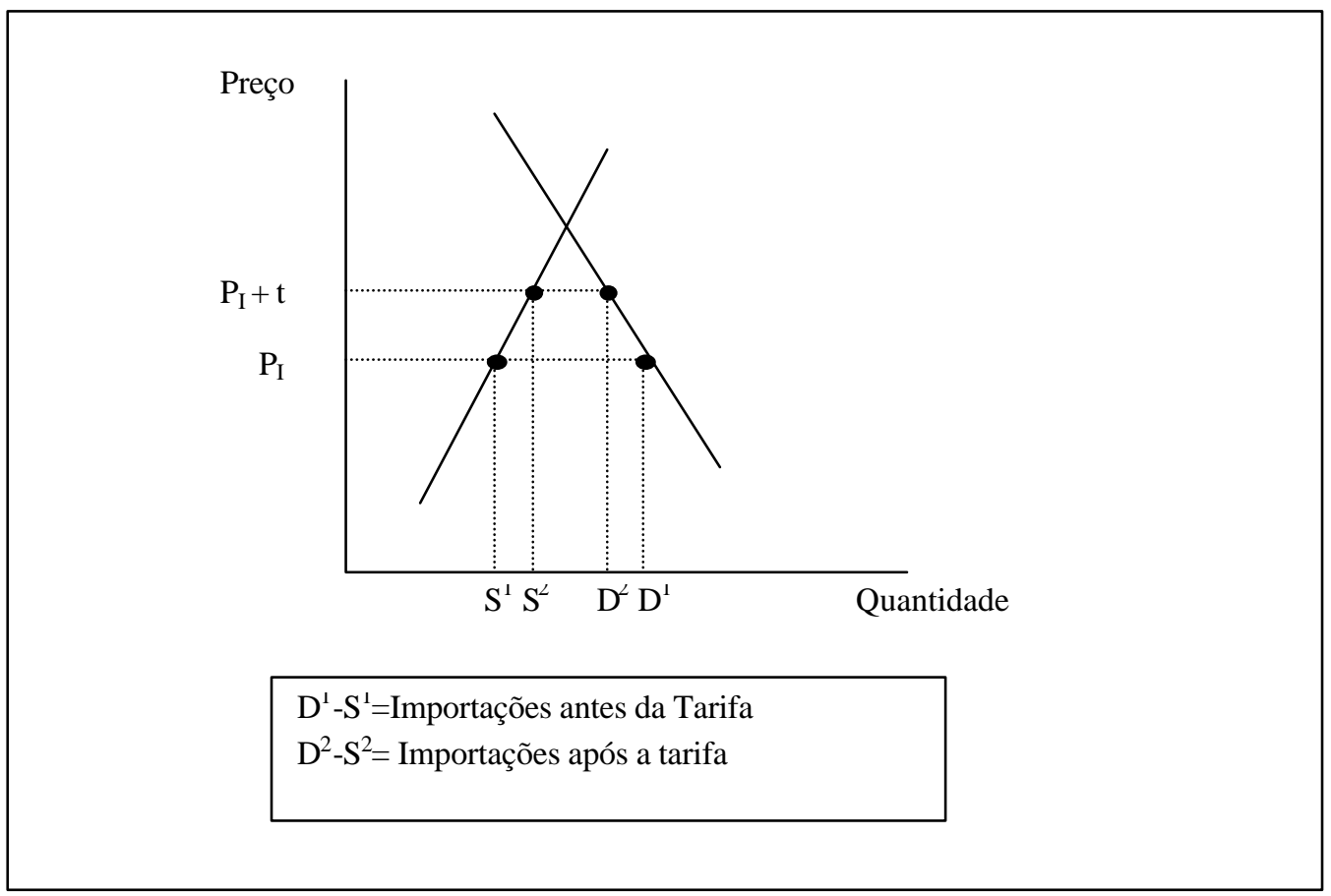

Figura 4 - Efeito da imposição de uma tarifa em um país pequeno.

Fonte: Krugman \& Obstfeld (1999)

Os picos tarifários, por sua vez, ocorrem quando $\mathrm{P}_{\mathrm{I}}+\mathrm{t}$ são elevados a ponto de impedir as importações desse produto. Os produtores internos são favorecidos, porém podem ocorrer outros fatores que obriguem a importação a preços ultraelevados, como a insuficiência de oferta dentro desse país.

Barreiras não-tarifárias são definidas como qualquer restrição, despesa, ou política, que não seja uma tarifa, que limite o acesso de produtos importados, como quotas, sistemas de licenciamento, regulamentos sanitários, proibições (OMC, 2003).

Essas barreiras não são definidas a priori com a intenção de restringir o comércio mas, sim de regulá-lo, impedir ações desleais, proteger a saúde e o meio-ambiente, etc. Entretanto pode-se detectar a utilização discriminatória de tais medidas com fins meramente comerciais (Castilho, 2000). 
As barreiras não-tarifárias podem causar efeitos sobre preço, quantidade, comércio, produção, consumo, renda, emprego e bem-estar. Esses efeitos podem ser diretos ou indiretos e afetam os países que as impõem e os demais países. As barreiras não-tarifárias muitas vezes são aplicadas sobre produtos que já estão sujeitos a barreiras tarifárias e, nesse caso, têm o efeito de aumentar a proteção a esses produtos. São de difícil quantificação, possuem custos para produtores, consumidores e exportadores, são pouco transparentes e discriminatórias. Causam uma distorção entre o preço doméstico e o preço internacional, fazendo com que a indústria doméstica não seja afetada pelas variações nos preços mundiais (Laird, 1998).

Dentre as barreiras não-tarifárias destacam-se principalmente as quotas tarifárias, barreiras sanitárias e fitossanitárias (SPS) e barreiras técnicas (TBT).

As quotas tarifárias são restrições de quantidade, através da imposição de tarifas mais elevadas quando o limite é ultrapassado, ou seja, até o limite da quota, as importações estão sujeitas a uma tarifa inferior (intra quota) àquela aplicada sobre as importações realizadas acima do limite da quota (extra quota).

A inclusão de quotas tarifárias na categoria de barreiras não-tarifárias deve-se ao fato de que as tarifas extra quota são muito elevadas, o que torna, muitas vezes, inviável a exportação de produtos acima da quota estabelecida.

Para analisar economicamente o sistema de quotas tarifárias, serão consideradas três situações, que estão representadas na figura 5. 


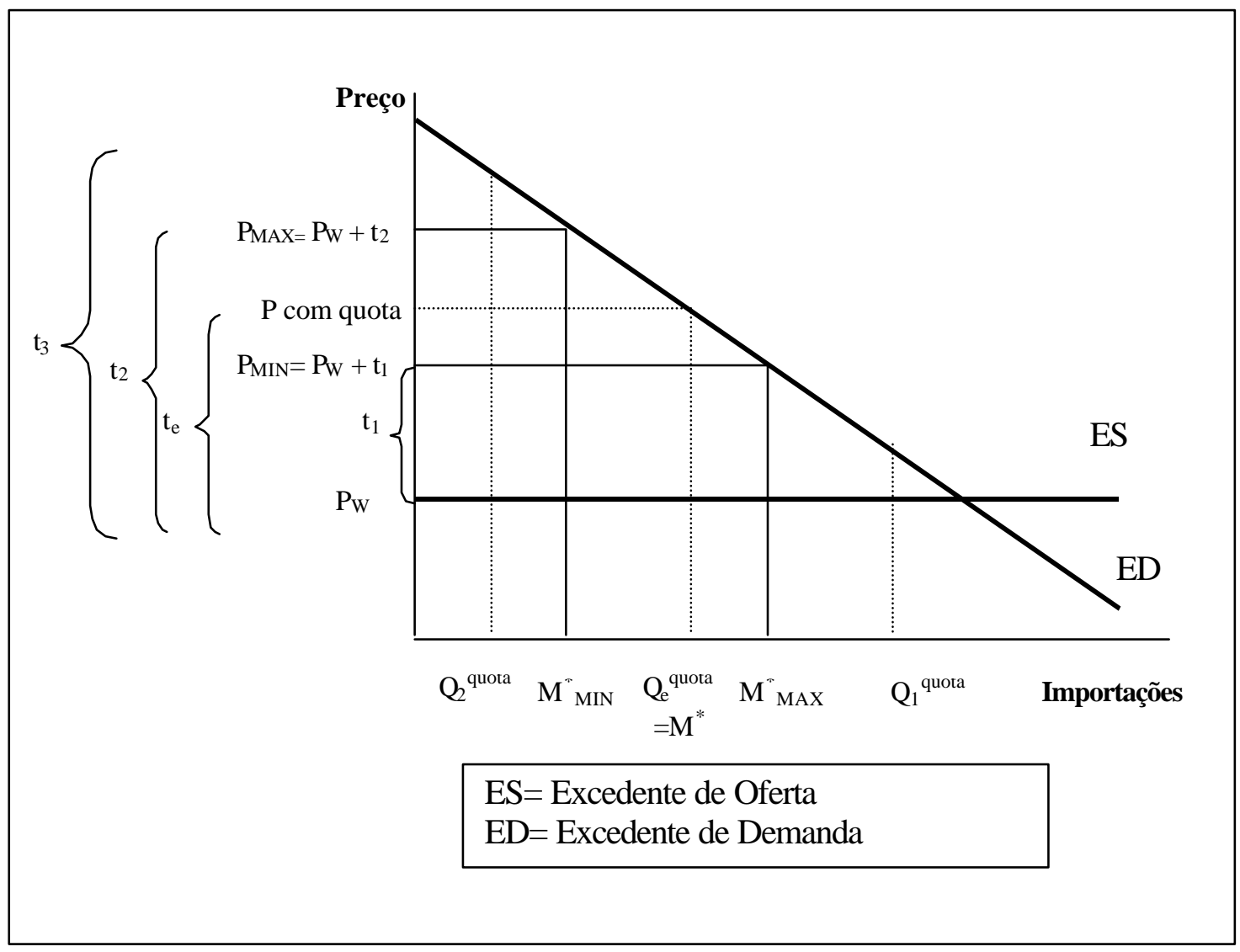

Figura 5 - Efeitos do uso de quotas tarifárias nas importações.

Fonte: DeGorter (2001)

Segundo a figura 5, quando o nível de acesso estabelecido na quota é alto e próximo ao nível que seria comercializado em uma situação de livre comércio $\left(\mathrm{Q}_{1}{ }^{\text {quota }}\right)$, a tarifa intra quota $\left(\mathrm{t}_{1}\right)$ torna-se efetiva e a quota torna-se redundante. Nesse caso o preço doméstico é $\left(\mathrm{P}_{\mathrm{W}}+\mathrm{t}_{1}\right)$, causando uma distorção no preço mundial igual a t.O equilíbrio ocorre quando a diferença entre o excesso de demanda e o excesso de oferta é igual à tarifa $\left(\mathrm{t}_{1}\right)$, nesse ponto é estabelecida a máxima quantidade importada $\left(\mathrm{M}^{*}{ }_{\text {MAX }}\right)$ e o preço é $\mathrm{P}_{\text {MIN }}$. Pode-se observar que a quantidade $\mathrm{Q}_{1}{ }^{\text {quota }}-\mathrm{M}^{*}{ }_{\text {MAX }}$ não é importada, não preenchendo a quota e demonstrando que o limitante, nesse caso, foi a tarifa intra quota. 
Quando o nível de acesso estabelecido na quota é muito baixo, próximo da origem dos eixos $\left(\mathrm{Q}_{2}{ }^{\text {quota }}\right)$, a tarifa extra quota $\left(\mathrm{t}_{2}\right)$ torna-se efetiva, determinando o nível mínimo de importação ( $\mathrm{M}_{\text {MIN }}^{*}$ ) e o preço máximo possível ( $\mathrm{P}_{\mathrm{MAX}}$ ). Nesse caso, a quantidade estabelecida na quota é menor que o nível mínimo de importação, portanto a tarifa a ser considerada será sempre a tarifa extra quota.

Se a quota estiver entre os níveis mínimo $\left(\mathrm{M}^{*}{ }_{\text {MIN }}\right)$ e máximo $\left(\mathrm{M}^{*}{ }_{\text {MAX }}\right)$ de importação, torna-se efetiva em determinar o preço doméstico e a quantidade importada. Essa quota está representada na figura 3 por $\mathrm{Q}_{\mathrm{e}}^{\text {quota }}$.

No caso da tarifa imposta ser maior ou igual a ţ, o comércio será impedido já que ao preço final $\left(\mathrm{P}_{\mathrm{W}}+\mathrm{t}_{3}\right)$ a demanda será igual a zero.

O quadro 2 resume os efeitos das três situações analisadas.

\begin{tabular}{|c|c|c|}
\hline Situação Inicial & $\begin{array}{l}\text { Mudança na Política } \\
\text { Redução de } \mathrm{t}_{1}\end{array}$ & $\begin{array}{l}\text { Efeito nas Importações } \\
+\end{array}$ \\
\hline \multirow[t]{2}{*}{$\mathrm{t}_{1}$ efetiva $\left(\mathrm{Q}_{1}{ }^{\text {quota }}\right)$} & Redução de $t_{2}$ & $\begin{array}{l}0 \\
+ \text { se } t_{2}<t_{1}\end{array}$ \\
\hline & Aumento da quota & 0 \\
\hline \multirow{3}{*}{$\mathrm{t} 2$ efetiva $\left(\mathrm{Q}_{2}{ }^{\text {quota }}\right)$} & Redução de $t_{1}$ & 0 \\
\hline & Redução de $t_{2}$ & + \\
\hline & Aumento da quota & $\begin{array}{l}0 \\
+ \text { se } M>M^{*} \text { MIN }\end{array}$ \\
\hline \multirow{3}{*}{ Quota efetiva $\left(\mathrm{Q}_{\mathrm{e}}^{\text {quota }}\right)$} & Redução de $\mathrm{t}_{1}$ & 0 \\
\hline & Redução de $t_{2}$ & $\begin{array}{l}0 \\
+ \text { se } M>Q_{e}{ }^{\text {quota }}\end{array}$ \\
\hline & Aumento da quota & + \\
\hline
\end{tabular}

Quadro 2 - Possíveis efeitos de alterações nas políticas de quotas tarifárias sobre as importações.

Fonte: DeGorter (2001) 
Segundo Barros et al. (2002) as medidas sanitárias e fitossanitárias (SPS) visam a impedir a disseminação de pragas e doenças entre plantas e animais, além de promover a segurança dos alimentos (food safety) para os consumidores. Quando essas medidas não cumprem o seu objetivo legítimo de proteger o consumidor e/ou o meio ambiente, tornam-se barreiras, caracterizando protecionismo.

O Acordo SPS da OMC foi criado para evitar que essas barreiras funcionem como forma de protecionismo e seguem dois princípios: (i) não discriminação; (ii) justificativa científica.

As barreiras técnicas derivam da utilização de normas ou regulamentos técnicos não-transparentes e/ou não embasados em normas internacionalmente aceitas.

Segundo Beghin \& Bureau (2001), as barreiras não-tarifárias são muito heterogêneas, sendo difícil estabelecer um modelo para descrevê-las. Não é possível estabelecer uma única metodologia para quantificá-las e geralmente utilizam-se métodos pertencentes a vários ramos da literatura econômica.

Outros exemplos de barreiras não-tarifárias encontram-se no Anexo. 


\subsubsection{Estudos que avaliaram a importância das barreiras}

O MDIC (2001), através da SECEX realizou um trabalho para identificar as barreiras impostas pelos principais parceiros comerciais do Brasil, qual seja ilustrar as diferentes estruturas de proteção dos países selecionados e sua incidência sobre as exportações brasileiras. Foram utilizadas informações do sistema TRAINS 2001 e do banco de dados da AMAD. Esse trabalho considerou as barreiras comerciais, fator determinante do baixo grau de crescimento das exportações brasileiras para os principais mercados. Subsídios, quotas, tarifas extremamente elevadas, escaladas e picos tarifários mantêm o crescimento do comércio agrícola próximo de sua tendência histórica, isto é, em cerca da metade do nível de crescimento do comércio global.

Nos Estados Unidos, mais de 130 itens estão sujeitos a tarifas acima de $35 \%$ e 311 acima de $15 \%$. Trinta e cinco produtos têm tarifas de 70 a $350 \%$ e vinte e nove de 50 a $70 \%$. Sessenta por cento dos produtos de exportação brasileiros são afetados por medidas restritivas no mercado americano. Importantes produtos agrícolas e industriais brasileiros estão sujeitos a picos tarifários, alguns da ordem de 200 a $\mathbf{5 0 \%}$ ad valorem (ou seu equivalente, quando específicas). Alguns exemplos são o fumo, que sofre uma tarifa de $350 \%$ extra quota, o açúcar, com uma tarifa de $159,3 \%$, e o suco de laranja, submetido a uma tarifa da ordem de $60 \%$ (equivalente ad valorem).

A União Européia, durante a Rodada Uruguai, consolidou todos os seus itens tarifários e, como os demais países membros da $\mathrm{OMC}$, acordou uma redução gradual da tarifa consolidada entre 1995 e 2000. O processo de redução tarifária vem promovendo a queda da tarifa aplicada, uma vez que as tarifas consolidadas finais foram estabelecidas abaixo da tarifa aplicada na época.

A estrutura tarifária da União Européia baseia-se numa elevada proteção efetiva aos produtos de maior valor agregado (escalada tarifária), estratégia que dificulta o acesso a esse mercado das exportações brasileiras desses produtos, favorecendo as exportações de bens de menor valor agregado.

Com relação às tarifas incidentes sobre as importações de produtos agropecuários, a tarifa média caiu de 25\%, em 1995, para 20,8\%, em 1997. Com base nas estatísticas da 
UNCTAD, a tarifa ad valorem média da União Européia era, em 1998, de 6,0\%, com um desvio padrão de 5,6\%. Num total de 14.251 itens tarifários (10 dígitos) sujeitos a tarifas ad valorem, 71 estavam sujeitos a tarifas acima de $25 \%$.

As tarifas ad valorem mais elevadas se concentram na seção 4 (produtos industrializados alimentares, bebidas e fumo). A maior incidência de tarifas específicas ocorre nas seções 1 (animais vivos e produtos do reino animal), 2 (produtos do reino vegetal) e na seção 4.

Nesse estudo, os picos tarifários foram definidos como tarifas situadas quatro desvios padrão acima da média (tarifas superiores a 28,3\%); nesse caso foram contabilizados 25 picos tarifários (a 10 dígitos) relativos a frutas, sucos de frutas, vinho, cigarros e outros produtos de fumo.

Adicionalmente, a União Européia aplica tarifas mistas (uma parcela do imposto é ad valorem e outra específica).

A tarifa de importação de alguns produtos, sobretudo frutas e vegetais, varia de acordo com a época do ano (tarifas sazonais), sendo que $11 \%$ dos itens da estrutura tarifária estão sujeitos a esse tipo de tarifa. É o caso, por exemplo, das importações de laranjas frescas, cujas tarifas estão classificadas de acordo com a época do ano e com o preço de entrada da laranja.

Com relação a barreiras não-tarifárias, as principais são relacionadas à sanidade animal, sanidade vegetal e quotas tarifárias. A exportação de carnes do Brasil para a União Européia é limitada diante da alegação da presença de doenças como febre aftosa (carne bovina), febre suína clássica (carne suína), doença de Newcastle (carne de frango).. As quotas tarifárias incidem principalmente sobre açúcar, bananas, carne bovina, carne de frango e suas tarifas extra quota são proibitivas.

Sobre as importações totais da UE, de 808 bilhões de dólares, os produtos agrícolas representam apenas 7,8\% (62.9 bilhões), o que reflete a eficácia do sistema de proteção nesse setor. Os produtos dos capítulos 1 a 24 (US\$ 10,1 bilhões) constituem $51 \%$ da pauta de exportações do Mercosul à União Européia, que é seu principal mercado agrícola. Observa-se ainda que essas exportações representam a expressiva parcela de $16 \%$ sobre o total das importações comunitárias de todo o mundo. Esses dados 
sugerem que o Mercosul dispõe de capacidade de exportação, em termos de volume e competitividade adequados para ampliar substancialmente sua participação no mercado comunitário na medida em que se reduzir o grau de proteção local.

Castilho (2000) calculou índices de frequiência e índices de cobertura ponderados pelas importações bilaterais para verificar o impacto das BNTs impostas pela União Européia com relação a vários países e blocos.

Os países e blocos mais afetados por essas medidas foram, principalmente os exportadores de produtos agrícolas. O Mercosul apresentou-se no grupo dos países mais penalizados na entrada no mercado europeu, com proteção tarifária e não-tarifária elevadas.

Verificou-se que dentre os setores sensíveis, o agrícola foi o que apresentou a maior regulação através de medidas de controle e restrição de importações impostas pela União Européia. A integração desse setor ao GATT não resultou em uma liberalização imediata, mas em perspectivas para uma liberalização futura e em disciplina mínima.

Pereira (1989) utilizou coeficientes de cobertura (CC) e de frequiência (CF) para estimar o efeito restritivo de barreiras não-tarifárias impostas pelos Estados Unidos, União Européia e Japão para o período de 1981 a 1986. Essa análise foi feita para todas as exportações por setores agregados, por grupo de medidas e discriminada por setores.

$\mathrm{O}$ coeficiente de frequiência mede o número de produtos importados sujeitos a BNTs, portanto pode ser interpretado como indicador de intenção de proteção. O coeficiente de cobertura mede a porcentagem do valor das exportações que está sujeita a BNTs.

Com relação a todas as exportações brasileiras, União Européia e Estados Unidos apresentaram coeficientes de cobertura mais elevados do que o Japão, evidenciando a maior relevância desses mercados para a pauta de exportações brasileira. Os coeficientes de frequiência da União Européia foram comparativamente mais elevados do que os calculados para os Estados Unidos, mas os coeficientes de cobertura foram menores, podendo levar a duas conclusões: as BNTs foram mais restritivas na União Européia ou afetaram produtos de maior valor nesse mercado. 
Para os produtos agropecuários, os coeficientes de frequiência e cobertura não variaram ao longo do tempo. Os Estados Unidos apresentaram coeficientes muito baixos (CF: 0,11\%, CC: 0,11\%), chegando a zero para o caso das exportações acima de US\$1.000.000. Os baixos coeficientes para esse setor são explicados, em parte, pela inclusão de produtos como açúcar e carne congelada no grupo de manufaturados. Esse grupo apresentou elevados coeficientes de cobertura e frequiência (35,12\% e 30,23\%, respectivamente).

A União Européia apresentou coeficientes de frequiência elevados e coeficientes de cobertura baixos para o setor agropecuário, sendo constante até 1984 (CF: 48,58\%, CC: 3,57\%) e apresentando um pequeno crescimento em 1985 (CF: 49,76\%, CC: 4,01\%) mantendo o mesmo valor em 1986. Segundo a autora, esse fato sugere que os produtos protegidos pela União Européia não são os mesmos exportados pelo Brasil.

A comparação entre os coeficientes calculados para esses dois parceiros comerciais do Brasil evidencia que a União Européia tem usado mais intensivamente as BNTs.

Vale ressaltar que produtos agroindustriais também não foram considerados separadamente nessa análise. Os setores de produtos alimentares, bebidas e fumo apresentaram índices de cobertura e frequiência bem altos, chegando a $100 \%$ na União Européia. 


\section{METODOLOGIA}

\subsection{Dados}

Para o cálculo da estimativa da porcentagem da pauta brasileira de exportações agrícolas, que é afetada pelos vários tipos de barreiras comerciais, foram levantadas barreiras tarifárias e não-tarifárias, impostas por destino (União Européia e Estados Unidos), para cada produto agrícola da pauta de exportações do Brasil, desagregado até o sexto dígito. Foram utilizados os valores de exportações agrícolas brasileiras com relação a esses destinos.

A utilização de dados relativos a linhas tarifárias a seis dígitos pode causar distorções nas análises, já que algumas barreiras incidem sobre apenas algumas linhas tarifárias a 8 dígitos. Ou seja, se uma barreira está incidindo sobre apenas um produto a 8 dígitos, quando ocorre a agregação desses itens a seis dígitos, essa barreira é considerada como se estivesse incidindo sobre todos os produtos que têm os seis primeiros dígitos em comum, superestimando o número e o valor das linhas tarifárias sujeitas a essa barreira.

Por outro lado, a utilização de linhas tarifárias a oito dígitos, além de resultar em um número muito grande de produtos, dificultando a análise, não segue uma nomenclatura universal, não permitindo o cruzamento dos dados, pois acima do sexto dígito a classificação é diferente para cada país.

O período considerado para análise foi o ano 2000, escolhido em função da disponibilidade de dados. A seleção dos produtos foi feita com base nos produtos agrícolas exportados pelo Brasil para o mundo no período considerado, para possibilitar a verificação de barreiras que possam estar impedindo o comércio. A classificação dos 
produtos agrícolas foi feita pela OMC e abrange todos os produtos dos capítulos 1 a 24 (exceto 3), e alguns itens dos capítulos 29, 33, 35, 38, 41, 43, 50, 51, 52, 53 (Anexo 1).

Os dados relativos às exportações brasileiras para o perí odo considerado foram obtidos no sistema ALICE do Ministério do Desenvolvimento, Indústria e Comércio (http://www.mdic.gov.br). Esse sistema contém dados a 8 dígitos segundo a Nomenclatura Comum do Mercosul (NCM). Como essa nomenclatura não é compatível com a utilizada pelos parceiros comerciais analisados, foi realizada a soma das exportações em valor (US\$) para cada linha tarifária a 6 dígitos.

Devido à dificuldade de distinção das medidas não-tarifárias utilizadas com fins puramente comerciais daquelas utilizadas com o objetivo legítimo, neste trabalho foi considerada a definição mais abrangente de barreira não-tarifária, ou seja, qualquer medida ou impedimento ao comércio que não tarifas. Com relação a essas barreiras, foram levantadas quotas tarifárias, barreiras sanitárias e fitossanitárias e barreiras técnicas. Com relação às barreiras tarifárias, foram levantadas tarifas e, através destas, foram identificados os picos tarifários.

Os dados relativos a barreiras sanitárias e fitossanitárias e barreiras técnicas foram obtidos na base TRAINS, tanto para os Estados Unidos como para a União Européia. Nessa base, os dados encontram-se disponíveis a 8 e 10 dígitos para os Estados Unidos e para a União Européia, respectivamente. Foi verificada a presença ou ausência dessas barreiras considerando os produtos exportados pelo Brasil a 6 dígitos. Essa agregação pode ter causado algum viés, já que uma barreira incidindo sobre um produto a 8 ou 10 dígitos pode não estar incidindo sobre todos os produtos que possuem os primeiros 6 dígitos em comum, conforme foi considerado na análise.

O levantamento das informações a respeito da presença de quotas tarifárias incidindo sobre os produtos selecionados, foi feito utilizando a base de dados da AMAD (http://www.amad.org). Essa base também disponibilizou dados relativos ao preço mundial, que foram utilizados para o cálculo do equivalente ad valorem para a União Européia. A base de dados da AMAD contém informações detalhadas a respeito de quotas tarifárias para os países da OMC que adotam esse tipo de restrição, além de dados de importação, tarifas e preço mundial. Esses dados seguem o sistema harmonizado de 
classificação (6 dígitos). Para este trabalho foram utilizadas apenas as informações a respeito da existência ou não de quotas para cada produto com relação a cada destino considerado.

Com relação a barreiras tarifárias foram consideradas as tarifas MFN. As tarifas impostas pelos Estados Unidos foram obtidas na base Hemisférica da ALCA. Nessa base, as tarifas específicas e mistas já se encontram convertidas em equivalente ad valorem. As tarifas impostas pela União Européia foram obtidas na base TRAINS. Para tarifas específicas foi calculado o equivalente ad valorem.

O método utilizado para o cálculo do equivalente ad valorem para a União Européia está descrito no Guia do Usuário da AMAD e consiste em dividir a tarifa específica pelo valor unitário de importação mundial e multiplicar por 100 para se obter o valor em porcentagem. $\mathrm{Na} \mathrm{AMAD}$, encontram-se disponíveis valores unitários de importação mundial em EURO/kg, EURO/unidade e EURO/litro.

Esses dados a respeito de tarifas estão disponíveis a 8 e 10 dígitos. Foi realizada a sua agregação para 6 dígitos, considerando o mais alto grau de proteção, ou seja, a tarifa máxima por linha tarifária a 6 dígitos. Esse método pode superestimar o valor das exportações que é afetado por picos tarifários, mas por outro lado permite corrigir a subestimação incorporada nesses valores devido à proibição ou restrição das exportações na presença de picos tarifários. A utilização da tarifa máxima visa a captar as tarifas que são realmente relevantes no comércio, como picos tarifários e tarifas extra quota, pois geralmente são essas tarifas elevadas que restringem o comércio. 


\subsection{Método}

As informações relativas à presença ou ausência de barreiras foram cruzadas com os dados de valores exportados. Para determinar a porcentagem das exportações agrícolas brasileiras que está sujeita a barreiras e a porcentagem que está livre de qualquer barreira foram utilizados os índices de frequiência e de cobertura.

Segundo Laird (1996) e Pereira (1989) o índice de cobertura permite estimar o montante do comércio sujeito às barreiras ou sua frequiência de aplicação sobre setores específicos ou países.

$$
C C i j=\left[\left(\sum_{i=1}^{m} M j m \times N j m\right) \div \sum_{i=1}^{m} M j m\right] \times 100
$$

CCij = coeficiente de cobertura das barreiras incidentes sobre o grupo $\mathrm{i}$, composto de $m$ linhas tarifárias, e impostas pelo país j

Mjm = é o valor das importações do país $\mathrm{j}$ de cada produto $\mathrm{m}$ pertencente ao grupo i

$$
\begin{aligned}
\mathrm{Njm} & =0, \text { se não existe incidência de barreira sobre o produto } \mathrm{m} \\
& =1, \text { se existe incidência de barreira sobre o produto } \mathrm{m} .
\end{aligned}
$$

$O$ índice de frequiência representa o percentual do fluxo de mercadorias pertencentes a um dado grupo, sujeito a BNTs em um país.

$$
C F i j=\left[\left(\sum_{i=1}^{m} L j m \times N j m\right) \div \sum_{i=1}^{m} L j m\right] \times 100
$$

CFij = coeficiente de frequência das barreiras incidentes no grupo i, composto de $\mathrm{m}$ Inhas tarifárias, e impostas pelo país $\mathrm{j}$

$$
\begin{aligned}
\text { Ljm } & =1 \text {, se o produto } \mathrm{m} \text { é exportado pelo país (Brasil) } \\
& =0 \text {, se o produto } \mathrm{m} \text { não é exportado pelo país (Brasil) }
\end{aligned}
$$


$\mathrm{Njm}=0$, se não existe incidência de barreira sobre o produto $\mathrm{m}$

$=1$, se existe incidência de barreira sobre o produto $\mathrm{m}$.

O $\sum \mathrm{Ljm}$, para todos os $\mathrm{i}=1, \ldots . \mathrm{m}$, representa o número de mercadorias que compõem o grupo $\mathrm{i}$.

\section{Considerações a respeito do método:}

Quanto mais restritiva é uma barreira, menor é o termo $\mathrm{Mg}_{\mathrm{M}}$, portanto menor é o peso atribuído a esta medida no cálculo do índice de cobertura. No extremo, se uma barreira é tão restritiva que impede todas as importações do item i do país j, o seu peso no cômputo será zero $\left(\mathrm{M}_{\mathrm{jM}}=0\right)$ e, em conseqüência, a proporção de cobertura de comércio será subestimada (Laird, 1996).

O índice de frequiência evita essa subestimação, por atribuir igual peso a todas as barreiras. Nos casos de proibição total de uma mercadoria, pode-se atribuir o valor 1 para $\mathrm{L}_{\mathrm{j} M}$, desde que exista um potencial efetivo de exportação do produto. No caso deste trabalho, considera-se que o Brasil tem potencial efetivo de exportação de um produto, quando esse produto foi exportado para algum de seus parceiros comerciais durante o período considerado.

$\mathrm{O}$ índice de frequiência não reflete o valor relativo dos produtos atingidos e, portanto, não reflete a importância das barreiras, comparativamente, entre itens de exportação.

Diante dessas limitações, a estimação de ambos os coeficientes, conjuntamente, permite uma melhor avaliação da incidência das barreiras. $\mathrm{O}$ quadro 3 apresenta a relação entre os índices de frequência (IF) e cobertura (IC).

Para o caso de picos tarifários os parâmetros dos índices de cobertura e frequiência, respectivamente foram os seguintes:

$$
C C i j=\left[\left(\sum_{i=1}^{m} M j m \times N j m\right) \div \sum_{i=1}^{m} M j m\right] \times 100
$$


CCij = coeficiente de cobertura das picos tarifários incidentes sobre produtos agrícolas exportados pelo Brasil, composto de m linhas tarifárias, e impostas pelo país $\mathrm{j}$ (Estados Unidos ou União Européia).

Mjm = é o valor das importações do país j (Estados Unidos ou União Européia) de cada produto $m$ pertencente à pauta de exportações agrícolas brasileira.

$\mathrm{Njm}=0$, se não existe incidência de picos tarifários sobre o produto $\mathrm{m}$ $=1$, se existe incidência de picos tarifários sobre o produto $\mathrm{m}$.

$$
C F i j=\left[\left(\sum_{i=1}^{m} L j m \times N j m\right) \div \sum_{i=1}^{m} L j m\right] \times 100
$$

CFij = coeficiente de frequência de picos tarifários incidentes sobre produtos agrícolas exportados pelo Brasil, composto de m linhas tarifárias, e impostas pelo país j (Estados Unidos ou União Européia).

$\mathrm{Ljm}=1$, se o produto $\mathrm{m}$ é exportado pelo Brasil. $=0$, se o produto $\mathrm{m}$ não é exportado pelo Brasil.

$\mathrm{Njm}=0$, se não existe incidência de pico tarifário sobre o produto $\mathrm{m}$. $=1$, se existe incidência de pico tarifário sobre o produto $\mathrm{m}$.

O $\sum$ Ljm, para todos os $\mathrm{i}=1, \ldots . \mathrm{m}$, representa o número de mercadorias que compõem o grupo i, ou seja, o número de linhas tarifárias referentes a produtos agrícolas exportados pelo Brasil.

Para o caso de barreiras não-tarifárias os parâmetros dos índices de cobertura e freqüência, respectivamente foram os seguintes:

$$
C C i j=\left[\left(\sum_{i=1}^{m} M j m \times N j m\right) \div \sum_{i=1}^{m} M j m\right] \times 100
$$

CCij $=$ coeficiente de cobertura das barreiras não-tarifárias incidentes sobre produtos agrícolas exportados pelo Brasil, composto de $\mathrm{m}$ linhas tarifárias, e impostas pelo país j (Estados Unidos ou União Européia). 
Mjm = é o valor das importações do país j (Estados Unidos ou União Européia) de cada produto $m$ pertencente à pauta de exportações agrícolas brasileira.

$\mathrm{Njm}=0$, se não existe incidência de barreiras não-tarifárias sobre o produto $\mathrm{m}$ $=1$, se existe incidência de barreiras não-tarifárias sobre o produto $\mathrm{m}$.

$$
C F i j=\left[\left(\sum_{i=1}^{m} L j m \times N j m\right) \div \sum_{i=1}^{m} L j m\right] \times 100
$$

CFij = coeficiente de frequência de barreiras não-tarifárias incidentes sobre produtos agrícolas exportados pelo Brasil, composto de $\mathrm{m}$ linhas tarifárias, e impostas pelo país j (Estados Unidos ou União Européia).

$\mathrm{Ljm}=1$, se o produto $\mathrm{m}$ é exportado pelo Brasil.

$=0$, se o produto $\mathrm{m}$ não é exportado pelo Brasil.

$\mathrm{Njm}=0$, se não existe incidência de barreiras não-tarifárias sobre o produto $\mathrm{m}$.

$=1$, se existe incidência de bar reiras não-tarifárias sobre o produto $\mathrm{m}$.

O $\sum$ Ljm, para todos os $\mathrm{i}=1, \ldots . \mathrm{m}$, representa o número de mercadorias que compõem o grupo i, ou seja, o número de linhas tarifárias referentes a produtos agrícolas exportados pelo Brasil.

Nas análises gerais, definiu-se como grupo i aquele que contém todos os produtos agrícolas segundo a classificação da OMC. Outras análises foram realizadas, considerando como grupo i cada capítulo e cada tipo de barreira não-tarifária aplicada, ou seja, os índices de cobertura e fequiência foram calculados para os produtos agrícolas em geral, para cada tipo de barreira e também para cada capítulo segundo o Sistema Harmonizado.

Como países j definiram-se Estados Unidos e União Européia separadamente. 


\begin{tabular}{|c|c|}
\hline Relação entre IC e IF & IF b aixo \\
\hline IC baixo & 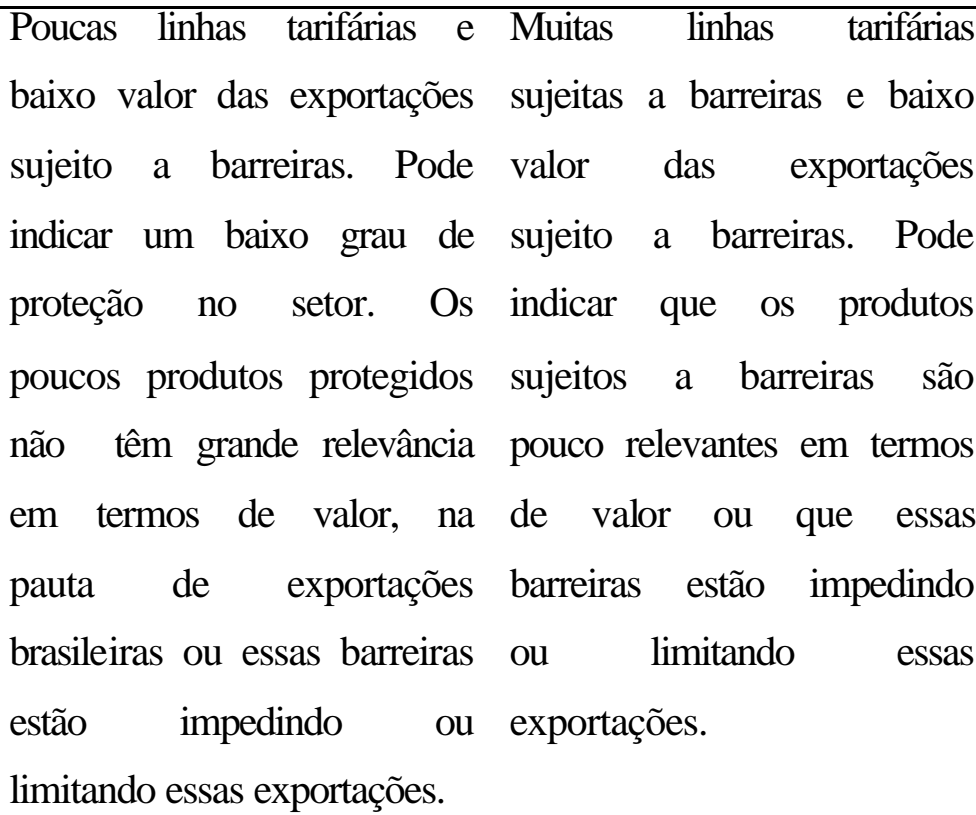 \\
\hline IC alto & 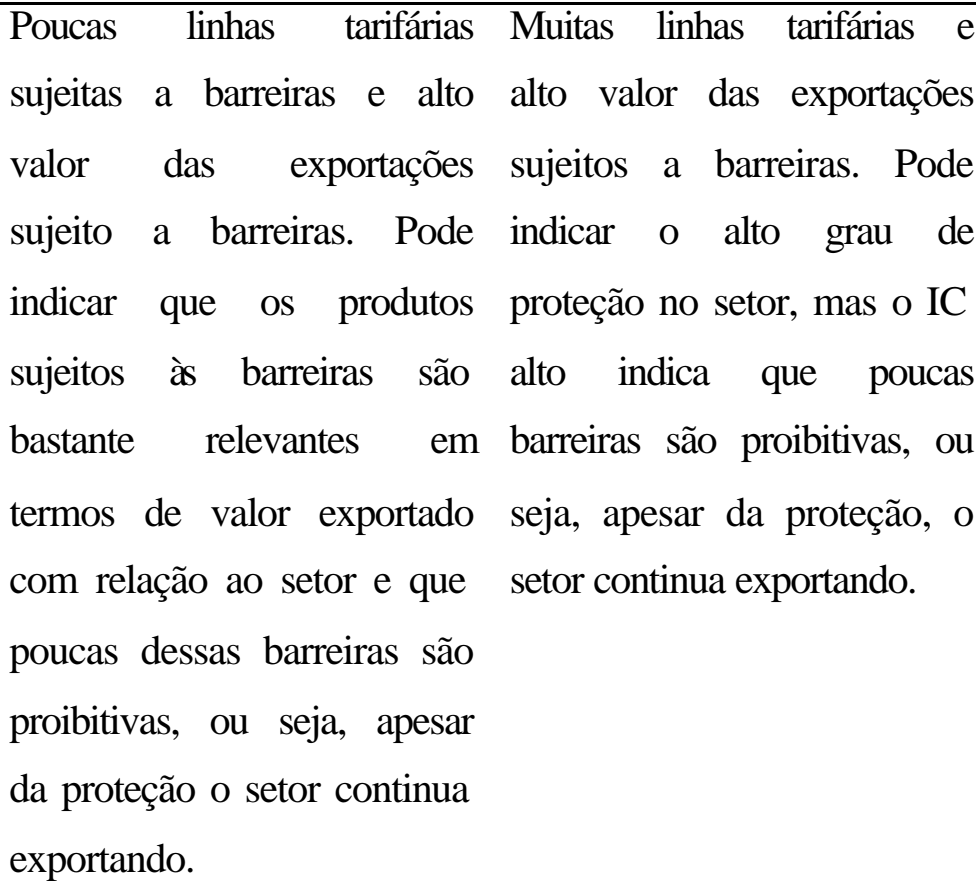 \\
\hline
\end{tabular}

Quadro 3 - Relação entre índice de frequiência e índice de cobertura.

Fonte: Elaborado com base em Laird (1996) 
Para verificar a frequiência e distribuição das tarifas, foram calculadas a média, mediana, tarifa máxima e o desvio- padrão dessas tarifas, sendo que média e mediana foram comparadas, segundo o método descrito em Gibson (2001). Nesse método, a relação entre essas duas estatísticas encontra-se expressa no Quadro 3.

\begin{tabular}{|l|l|l|l|}
\hline $\begin{array}{l}\text { Relação entre média } \\
\text { mediana }\end{array}$ & $\begin{array}{l}\text { Mediana Alta } \\
\text { um país para um setor na } \\
\text { maioria das rinhas Alta }\end{array}$ & $\begin{array}{l}\text { Mediana Baixa } \\
\text { tarifárias. }\end{array}$ & $\begin{array}{l}\text { Nível extremamente alto de } \\
\text { proteção para poucas } \\
\text { commodities, entretanto a } \\
\text { maioria das linhas tarifárias } \\
\text { estão sujeitas a tarifas } \\
\text { baixas. }\end{array}$ \\
\hline Média Baixa & $\begin{array}{l}\text { Nível extremamente baixo } \\
\text { de proteção para poucas } \\
\text { commodities, entretanto a a a } \\
\text { maioria das linhas tarifárias } \\
\text { estão sujeitas a tarifas } \\
\text { elevadas. }\end{array}$ & $\begin{array}{l}\text { Baixos níveis de proteção } \\
\text { de um país para um setor, } \\
\text { na maioria das linhas } \\
\text { tarifárias. }\end{array}$ \\
\hline
\end{tabular}

Quadro 4 - Relação entre média e mediana.

Fonte: Elaborado com base em Gibson(2001)

Com a finalidade de verificar a distribuição das tarifas, foi realizada uma classificação da porcentagem afetada em intervalos tarifários. 


\section{RESULTADOS E DISCUSSÃO}

\subsection{Barreiras tarifárias}

Com relação às barreiras tarifárias, foram analisadas a presença de picos tarifários, baseada em seus índices de frequiência e de cobertura, e a estrutura tarifária dos Estados Unidos e União Européia, baseada em estatísticas.

Picos tarifários foram definidos como tarifas acima de 15\%. Os Estados Unidos apresentaram um índice de frequiência menor que o índice de cobertura. Isso evidencia que poucas linhas tarifárias são protegidas através de picos tarifários e que essas linhas são muito relevantes, em termos de valor exportado, ou os picos tarifários não estão impedindo o comércio.

A União Européia apresentou um índice de frequiência maior que o índice de cobertura, evidenciando a proteção de um maior número de linhas tarifárias com menor valor em relação às exportações agrícolas totais do Brasil para esse parceiro comercial ou, ainda, que esses picos são eficientes na proteção do mercado europeu por restringirem ou limitarem o comércio desses produtos (Tabela 1).

Tabela 1. Índices de frequiência e cobertura de picos tarifários sobre as exportações agrícolas brasileiras para Estados Unidos e União Européia, em 2000.

\begin{tabular}{ccc}
\hline Indices & EUA & UE \\
\hline IF & $14 \%$ & $37 \%$ \\
IC & $37 \%$ & $26 \%$
\end{tabular}

Fonte: Cálculo com base em BDH, TRAINS, ALICE Web. 
A Tabela 2 mostra que a estrutura tarifária dos Estados Unidos baseia-se em tarifas elevadas para alguns produtos, mas que a maioria dos produtos agrícolas exportados pelo Brasil estão sujeitos a tarifas baixas (média alta e mediana baixa). O desvio- padrão mede a dispersão das tarifas em torno da média.

A tarifa máxima aplicada pelos Estados Unidos é de 350\% e incide sobre tabaco. Outros produtos que apresentaram tarifas bastante elevadas foram: preparações de cereais para alimentação infantil, leite em pó e alguns outros laticínios, chocolates, produtos de amendoim, alguns resíduos utilizados para a alimentação animal, coco em pó, açúcar, etc. Alguns produtos que apresentaram importância em termos de valor, com relação às exportações brasileiras, foram: tabaco, suco de laranja, açúcar, chocolate e outras preparações contendo cacau.

Tabela 2. Estatísticas das tarifas dos Estados Unidos para produtos agrícolas em 2000.

\begin{tabular}{cc}
\hline Média & $13,22 \%$ \\
Mediana & $2,00 \%$ \\
Máxima & $350,00 \%$ \\
Desvio- Padrão & $43 \%$ \\
\hline
\end{tabular}

Fonte: Cálculo com base em BDH.

A maior parte do valor de exportação dos produtos agrícolas brasileiros para os Estados Unidos, não está sujeita a picos tarifários. Da parcela das exportações agrícolas sujeita a picos, a maioria encontra-se na faixa tarifária de 50 a 100\%. (Tabela 3). 
Tabela 3. Estrutura tarifária dos Estados Unidos para produtos agrícolas em 2000 expressa em \% do valor.

\begin{tabular}{cc}
\hline Intervalo tarifário & 2000 \\
\hline Valor Não Sujeito a Picos Tarifários (0-15) & $63 \%$ \\
$15-30$ & $1 \%$ \\
$30-50$ & $8 \%$ \\
$50-100$ & $17 \%$ \\
$>100$ & $11 \%$ \\
\hline
\end{tabular}

Fonte: Cálculo com base em BDH e AliceWeb.

Segundo a tabela 4, os capítulos de oleaginosos, gorduras, bebidas alcoólicas e vinagres, resíduos das indústrias alimentares apresentaram índices de freqüência e de cobertura baixos, ou seja, poucas linhas tarifárias protegidas por picos tarifários e pouca relevância de valor dos produtos exportados sujeitos a tal restrição.

Os capítulos de carnes, plantas, raízes e tubérculos comestíveis, açúcares e confeitaria e preparações de produtos de origem vegetal apresentaram índices de frequiência menores que os respectivos índices de cobertura, indicando que poucas linhas tarifárias encontram-se protegidas e que o valor exportado correspondente a essas linhas é bastante alto, ou seja, a incidência dos picos tarifários ocorre exatamente sobre as linhas tarifárias relevantes nas exportações brasileiras.

Os capítulos de cacau, preparações à base de cereais, preparações alimentícias diversas e algodão apresentaram índices de freqüência maiores que os índices de cobertura, ou seja, esses capítulos apresentaram muitas linhas tarifárias com incidência de picos tarifários e o valor afetado foi baixo, podendo indicar a irrelevância do valor comercializado desses produtos com os Estados Unidos ou a limitação do comércio através desse instrumento de proteção. Não houve exportações de algodão.

Os capítulos de leite, laticínios e ovos e de fumo apresentaram os índices de freqüência e cobertura mais altos, indicando uma alta proteção nesses setores. $O$ índice de cobertura foi próximo a $100 \%$ em ambos os casos, indicando que praticamente todos os produtos, pertencentes a esses capítulos, exportados pelo Brasil para os Estados 
Unidos, estão sujeitos a picos. Entretanto, houve comércio desses produtos, ou seja, os picos tarifários não impediram totalmente as exportações brasileiras para os Estados Unidos.

Os demais capítulos não apresentaram proteção através de picos tarifários.

Tabela 4. Índices de frequiência e cobertura para picos tarifários sobre as exportações agrícolas brasileiras para os Estados Unidos, considerando os capítulos segundo o sistema harmonizado, 2000.

\begin{tabular}{|c|c|c|c|}
\hline Capítulo & Descrição & IF & IC \\
\hline 1 & Animais vivos. & $0 \%$ & $0 \%$ \\
\hline 2 & Carnes. & $13 \%$ & $26 \%$ \\
\hline 4 & Leite, laticínios e ovos. & $74 \%$ & $97 \%$ \\
\hline 5 & Outros produtos de origem animal. & $0 \%$ & $0 \%$ \\
\hline 6 & Plantas vivas. & $0 \%$ & $0 \%$ \\
\hline 7 & Produtos hortícolas, raízes e tubérculos comestíveis. & $17 \%$ & $72 \%$ \\
\hline 8 & Frutas. & $4 \%$ & $0 \%$ \\
\hline 9 & Café, chá e especiarias. & $0 \%$ & $0 \%$ \\
\hline 10 & Cereais. & $0 \%$ & $0 \%$ \\
\hline 11 & Produtos da indústria de moagem. & $0 \%$ & $0 \%$ \\
\hline 12 & Oleaginosos. & $6 \%$ & $0 \%$ \\
\hline 13 & Gomas, resinas. & $0 \%$ & $0 \%$ \\
\hline 14 & Matérias para entrançar. & $0 \%$ & $0 \%$ \\
\hline 15 & Gorduras. & $8 \%$ & $0 \%$ \\
\hline 16 & Preparações de carne. & $0 \%$ & $0 \%$ \\
\hline 17 & Açúcares, confeitaria. & $56 \%$ & $97 \%$ \\
\hline 18 & Cacau. & $36 \%$ & $12 \%$ \\
\hline 19 & Preparações à base de cereais, etc. & $18 \%$ & $14 \%$ \\
\hline 20 & Preparações de produtos de origem vegetal. & $23 \%$ & $90 \%$ \\
\hline 21 & Preparações alimentícias diversas. & $31 \%$ & $6 \%$ \\
\hline 22 & Bebidas alcoólicas e vinagres. & $9 \%$ & $9 \%$ \\
\hline 23 & Resíduos das indústrias alimentares. & $5 \%$ & $0 \%$ \\
\hline 24 & Fumo (tabaco). & $67 \%$ & $98 \%$ \\
\hline 29 & Produtos químicos orgânicos. & $0 \%$ & $0 \%$ \\
\hline 33 & Óleos essenciais e resinóides. & $0 \%$ & $0 \%$ \\
\hline 35 & Matérias albuminóides. & $0 \%$ & $0 \%$ \\
\hline 38 & Produtos diversos das indústrias químicas. & $0 \%$ & $0 \%$ \\
\hline 41 & Peles e couros. & $0 \%$ & $0 \%$ \\
\hline 43 & Peleteria. & $0 \%$ & $0 \%$ \\
\hline 50 & Seda. & $0 \%$ & $\mathrm{n} / \mathrm{a}$ \\
\hline 51 & Lã e pêlos. & $0 \%$ & $0 \%$ \\
\hline 52 & Algodão. & $25 \%$ & $\mathrm{n} / \mathrm{a}$ \\
\hline 53 & Fios de papel. & $0 \%$ & $\mathrm{n} / \mathrm{a}$ \\
\hline
\end{tabular}

Fonte: Cálculo com base em BDH e AliceWeb. 
Segundo a tabela 5, a União Européia apresenta uma estrutura tarifária baseada em alto nível de proteção para poucos produtos agrícolas, sendo que a maioria não está sujeita a picos tarifários, ou indicando que a presença de picos tarifários está limitando ou impedindo o comércio. Entretanto, apresenta média e mediana maiores que os Estados Unidos, o que evidencia que a maioria dos produtos protegidos por picos tarifários apresentam tarifas mais elevadas que as dos Estados Unidos. O desvio- padrão é menor do que o apresentado pelos Estados Unidos, evidenciando uma menor dispersão das tarifas em torno da média na União Européia.

Tabela 5. Estatísticas das tarifas para produtos agrícolas da União Européia em 2000.

\begin{tabular}{cc}
\hline Média & $21,35 \%$ \\
Mediana & $9,60 \%$ \\
Máxima & $251,6 \%$ \\
Desvio- Padrão & $32 \%$ \\
\hline
\end{tabular}

Fonte: Cálculo com base no TRAINS.

A tarifa máxima foi de 251,6\%, incidindo sobre sobras de carne comestíveis. Outros produtos que apresentaram tarifas elevadas foram: cogumelos, leite e derivados, carne bovina congelada, vegetais e manteiga. Com relação à importância dos picos em termos de valor para o Brasil, os principais produtos foram: carne bovina, suco de laranja, tabaco, bananas, açúcar, carne suína e álcool.

A tabela 6 res salta um maior uso de tarifas na faixa de 30 a $50 \%$ por esse parceiro comercial do Brasil. 
Tabela 6. Estrutura tarifária da União Européia para produtos agrícolas em 2000 expressa em $\%$ do valor.

\begin{tabular}{cc}
\hline Intervalo & 2000 \\
\hline Valor Não Sujeito a Picos Tarifários (0-15) & $74 \%$ \\
$15-30$ & $1 \%$ \\
$30-50$ & $18 \%$ \\
$50-100$ & $2 \%$ \\
$>100$ & $4 \%$ \\
\hline
\end{tabular}

Fonte: Cálculo com base em TRAINS.

Segundo a tabela 7 , os capítulos de plantas, raízes e tubérculos comestíveis, frutas, preparações alimentícias diversas e gorduras apresentaram índices de freqüência e de cobertura baixos, ou seja, poucas linhas tarifárias protegidas e pouca relevância de valor dos produtos exportados sujeitos a picos tarifários.

Os capítulos de gomas e resinas e de bebidas alcoólicas e vinagres apresentaram índices de frequiência bem menores que os respectivos índices de cobertura, indicando que algumas linhas tarifárias se encontram protegidas e que o valor exportado correspondente a essas linhas é bastante alto.

Os capítulos de animais vivos, produtos da ndústria de moagem, cacau, resíduos das indústrias alimentares, fumo, matérias albuminóides apresentaram índices de frequiência bem maiores que os índices de cobertura, ou seja, esses capítulos apresentaram muitas linhas tarifárias com incidência de picos tarifários e o valor afetado foi baixo, podendo indicar a irrelevância do valor comercializado desses produtos ou a limitação do comércio através desse instrumento de proteção. No caso de animais vivos e resíduos das indústrias alimentares, as exportações não ocorreram.

Os capítulos de carnes, leite, laticínios e ovos, cereais, preparações de carne, açúcares e confeitaria, preparações à base de cereais, preparações de produtos de origem vegetal, produtos químicos orgânicos apresentaram índices de frequiência muito altos e índices de cobertura próximos a 100\%. Os altos índices de frequiência sinalizam uma elevada proteção desses setores através da utilização de picos tarifários. Os índices de cobertura próximos a 100\% indicam que praticamente todos os produtos agrícolas, 
pertencentes a esses capítulos, exportados pelo Brasil para a União Européia, estão sujeitos a esse mecanismo de proteção. Entretanto, os picos tarifários não impediram totalmente esse comércio.

Os demais capítulos não apresentaram proteção através de picos tarifários.

Tabela 7. Índices de frequiência e de cobertura para picos tarifários sobre as exportações agrícolas brasileiras para União Européia em 2000, considerando os capítulos segundo o sistema harmonizado.

\begin{tabular}{|c|c|c|c|}
\hline Capítulo & Descrição & IF & IC \\
\hline 1 & Animais vivos. & $31 \%$ & $0 \%$ \\
\hline 2 & Carnes. & $74 \%$ & $97 \%$ \\
\hline 4 & Leite, laticínios e ovos. & $89 \%$ & $100 \%$ \\
\hline 5 & Outros produtos de origem animal. & $0 \%$ & $0 \%$ \\
\hline 6 & Plantas vivas. & $0 \%$ & $0 \%$ \\
\hline 7 & Produtos hortícolas, raízes e tubérculos comestíveis. & $12 \%$ & $7 \%$ \\
\hline 8 & Frutas. & $16 \%$ & $21 \%$ \\
\hline 9 & Café, chá e especiarias. & $0 \%$ & $0 \%$ \\
\hline 10 & Cereais. & $73 \%$ & $100 \%$ \\
\hline 11 & Produtos da indústria de moagem. & $61 \%$ & $10 \%$ \\
\hline 12 & Oleaginosos. & $0 \%$ & $0 \%$ \\
\hline 13 & Gomas, resinas. & $8 \%$ & $30 \%$ \\
\hline 14 & Matérias para entrançar. & $0 \%$ & $0 \%$ \\
\hline 15 & Gorduras. & $18 \%$ & $0 \%$ \\
\hline 16 & Preparações de carne. & $91 \%$ & $100 \%$ \\
\hline 17 & Açúcares, confeitaria. & $75 \%$ & $100 \%$ \\
\hline 18 & Cacau. & $45 \%$ & $2 \%$ \\
\hline 19 & Preparações à base de cereais, etc. & $65 \%$ & $100 \%$ \\
\hline 20 & Preparações de produtos de origem vegetal. & $82 \%$ & $100 \%$ \\
\hline 21 & Preparações alimentícias diversas. & $13 \%$ & $3 \%$ \\
\hline 22 & Bebidas alcoólicas e vinagres. & $32 \%$ & $52 \%$ \\
\hline 23 & Resíduos das indústrias alimentares. & $32 \%$ & $0 \%$ \\
\hline 24 & Fumo (tabaco). & $89 \%$ & $11 \%$ \\
\hline 29 & Produtos químicos orgânicos. & $67 \%$ & $100 \%$ \\
\hline 33 & Óleos essenciais e resinóides. & $0 \%$ & $0 \%$ \\
\hline 35 & Matérias albuminóides. & $40 \%$ & $11 \%$ \\
\hline 38 & Produtos diversos das indústrias químicas. & $0 \%$ & $0 \%$ \\
\hline 41 & Peles e couros. & $0 \%$ & $0 \%$ \\
\hline 43 & Peleteria. & $0 \%$ & $0 \%$ \\
\hline 50 & Seda. & $0 \%$ & $0 \%$ \\
\hline 51 & Lã e pêlos. & $0 \%$ & $0 \%$ \\
\hline 52 & Algodão. & $0 \%$ & $0 \%$ \\
\hline 53 & Fios de papel. & $0 \%$ & $0 \%$ \\
\hline
\end{tabular}

Fonte: Cálculo com base em TRAINS e ALICEWeb. 


\subsection{Barreiras não-tarifárias}

Com relação às barreiras não-tarifárias, este trabalho avaliou quotas tarifárias e as demais barreiras não-tarifárias utilizadas pelos Estados Unidos e União Européia relacionadas no TRAINS.

Observando-se a tabela 8, pode-se verificar que os Estados Unidos empregaram mais amplamente medidas de proteção baseadas em barreiras não-tarifárias do que a União Européia.

Tabela 8. Porcentagem da pauta de exportações agrícolas brasileiras sujeitas a algum tipo de barreira não-tarifária nos Estados Unidos e União Européia em 2000, expressa em \% do valor (US\$ FOB).

\begin{tabular}{ccc}
\hline Ano & Estados Unidos & União Européia \\
\hline 2000 & $68 \%$ & $27 \%$ \\
\hline
\end{tabular}

Fonte: Cálculo com base no TRAINS.

Nos Estados Unidos, o índice de frequiência apresentado para 2000 foi maior que o índice de cobertura, ou seja, muitas linhas tarifárias estão sendo afetadas por quotas tarifárias, porém a parcela do valor afetado não é tão grande, podendo levar à conclusão de que os produtos agrícolas exportados sujeitos a quotas não têm grande relevância em termos de valor ou, ainda, que essas barreiras estão impedindo ou limitando as exportações daqueles produtos, o que se refletiu na diminuição do valor exportado (Tabela 9).

Os capítulos que apresentaram maior número de linhas tarifárias sujeitas a quotas tarifárias foram: leite, laticínios e ovos, cacau, preparações alimentícias diversas, preparações à base de cereais, açúcares e confeitaria, fumo (tabaco) e carnes. Em termos de valor,os capítulos que apresentaram maior relevância foram: fumo (tabaco), açúcares e confeitaria, cacau, preparações alimentícias diversas e preparações à base de cereais. 
Os principais produtos em termos de valor exportado pelo Brasil, sujeitos a esse tipo de restrição nos Estados Unidos foram tabaco, açúcar de cana, açúcar para confeitaria, chocolate e preparações contendo cacau, preparações alimentícias diversas e açúcar sólido.

Os índices de cobertura e frequiência apresentados para a União Européia foram muito próximos, sendo que o índice de frequiência foi um pouco maior, indicando que a porcentagem das linhas tarifárias afetadas por quotas tarifárias é maior do que a porcentagem do valor afetado por elas. (Tabela 9).

Os principais capítulos atingidos, em termos de número de linhas tarifárias, foram: carnes, leite, laticínios e ovos, cereais, frutas, plantas, raízes e tubérculos comestíveis, preparações de carne e animais vivos. Em termos de valor afetado, os principais capítulos foram: preparações de produtos de origem vegetal, carnes, frutas, açúcares e confeitaria, bebidas alcoólicas e vinagres, resíduos de indústrias alimentares, plantas, raízes e tubérculos comestíveis.

Os principais produtos, em termos de valor exportado pelo Brasil, sujeitos a quotas tarifárias na União Européia foram: suco de laranja congelado, carne bovina desossada e congelada, cortes e sobras comestíveis de carnes de aves congelados, carne bovina desossada fresca ou resfriada, maçãs frescas, laranjas frescas ou resfriadas, uvas frescas, carne suína congelada, aves inteiras congeladas, açúcar de cana.

Tabela 9. Índice de cobertura e índice de frequiência para quotas tarifárias sobre as exportações agrícolas brasileiras para os Estados Unidos e União Européia (2000).

\begin{tabular}{ccccc}
\hline \multirow{2}{*}{ Ano } & \multicolumn{2}{c}{ Estados Unidos } & \multicolumn{2}{c}{ União Européia } \\
& IC & IF & IC & IF \\
\hline 2000 & $19 \%$ & $36 \%$ & $22 \%$ & $27 \%$ \\
\hline
\end{tabular}

Fonte: Cálculo com base em ALICEWeb e AMAD. 
As principais barreiras não-tarifárias impostas pelos Estados Unidos foram (Tabela 10):

- Medidas antidumping

- Direitos Compensatórios

- Medidas para proteção da saúde animal

○ autorização para proteção da saúde animal

○ requerimentos de teste, inspeção ou quarentena para proteção da saúde animal

- Medidas para proteção da saúde humana

○ autorização para proteção da vida humana

- requerimentos de etiquetagem para proteção da saúde humana

○ requerimento de marca para proteção da saúde humana

○ requerimentos de características do produto para proteção da saúde humana

- requerimentos de teste, inspeção ou quarentena para proteção da saúde humana

- Medidas para proteção da saúde das plantas

○ autorização para proteção da saúde das plantas

- requerimentos de características do produto para proteção da saúde das plantas

○ requerimentos de teste, inspeção ou quarentena para proteção da saúde das plantas

- Medidas para proteção da vida selvagem

○ autorização para proteção da vida selvagem

- Medidas para controle do uso de drogas

- requerimentos de características do produto para controle do uso de drogas

- Medidas Gerais

- requerimentos de etiquetagem

○ licença para compradores selecionados 
○ requerimentos de marca

○ quotas para controle

Nos Estados Unidos, direitos antidumping e direitos compensatórios apresentaram altos índices de cobertura, maiores que os respectivos índices de frequiência, indicando que poucas linhas tarifárias são afetadas por essas medidas, mas que os produtos sujeitos a essas barreiras têm grande relevância em termos de valor ou que essas barreiras não impedem o comércio dos produtos sobre os quais incidem.

As medidas autorização para proteção da vida humana, requerimentos de etiquetagem para proteção da saúde humana, requerimento de marca para proteção da saúde humana, requerimentos de características do produto para proteção da saúde das plantas, requerimentos de características do produto para controle do uso de drogas e requerimentos de teste, quota para controle, requerimentos de teste, inspeção ou quarentena para proteção da saúde das plantas- apresentaram índices de frequiência e índices de cobertura baixos, muitas vezes próximos de zero. Os índices de freqüência baixos indicam que poucos produtos são afetados por essas medidas. Os índices de cobertura também baixos podem indicar que esses produtos têm pouca relevância na pauta de exportações agrícolas brasileiras ou, ainda, que essas barreiras estão restringindo ou proibindo o comércio dos produtos sujeitos a elas (Tabela 10).

As medidas autorização para proteção da saúde animal, autorização para proteção da vida selvagem, licença para compradores selecionados, requerimentos de marca, requerimentos de características do produto para proteção da saúde humana, requerimentos de teste, inspeção ou quarentena para proteção da saúde animal e requerimentos de teste, inspeção ou quarentena para proteção da saúde humanaapresentaram índices de frequiência mais altos que os índices de cobertura, que muitas vezes foram próximos de zero. Nesse caso, fica mais nítida a restrição das barreiras com relação ao valor exportado, ou ainda, a irrelevância, em termos de valor, das linhas tarifárias sujeitas a tais barreiras.

Ainda analisando a tabela 10, pode-se verificar que as principais barreiras nãotarifárias em termos do valor afetado foram: medidas antidumping, taxas de 
compensação, requerimentos de características do produto para proteção da saúde humana, requerimentos de teste, inspeção ou quarentena para proteção da saúde humana.

Tabela 10. Índices de freqüência e de cobertura para os diferentes tipos de BNTs sobre as exportações agrícolas brasileiras, impostas pelos Estados Unidos, 2000.

\begin{tabular}{ccc}
\hline Barreira Não-Tarifária & 2000 & IC \\
\hline Medidas Antidumping & $0,1 \%$ & $16,9 \%$ \\
Medidas Compensatórias & $0,2 \%$ & $16,9 \%$ \\
Medidas para Proteção da Saúde Animal & $9,6 \%$ & $0,5 \%$ \\
Medidas para Proteção da Saúde Humana & $88,7 \%$ & $34,4 \%$ \\
Medidas para Proteção da Saúde das Plantas & $41,5 \%$ & $14,9 \%$ \\
Medidas para Proteção da Vida Selvagem & $6,0 \%$ & $0,5 \%$ \\
Medidas para Controle do Uso de Drogas & $0,5 \%$ & $0,6 \%$ \\
Medidas Gerais & $24,6 \%$ & $8,2 \%$ \\
\hline
\end{tabular}

Fonte: Cálculo com base no TRAINS e AliceWeb. 


\begin{tabular}{|c|c|}
\hline Barreira Não-Tarifária & Produtos \\
\hline Quotas tarifárias & $\begin{array}{l}\text { Tabaco, açúcar de cana, açúcar para confeitaria, chocolate e } \\
\text { preparações contendo cacau, preparações alimentícias diversas e } \\
\text { açúcar sólido. }\end{array}$ \\
\hline Medidas Antidumping & Suco de laranja congelado \\
\hline Direitos Compensatórios & Suco de laranja congelado e óleo de rícino não refinado. \\
\hline $\begin{array}{c}\text { Medidas para Proteção da } \\
\text { Saúde Animal }\end{array}$ & Produtos de origem animal, cavalos vivos. \\
\hline $\begin{array}{l}\text { Medidas para Proteção da } \\
\text { Saúde Humana }\end{array}$ & $\begin{array}{l}\text { Suco de laranja congelado, carne bovina e restos preparados ou em } \\
\text { conserva, extratos, essências e concentrados de café, açúcar para } \\
\text { confeitaria, suco de maçã, goiabas e mangas frescas ou secas, bolachas } \\
\text { doces, suco de uva, suco de laranja, coração de palmito preparado ou } \\
\text { em conserva. }\end{array}$ \\
\hline $\begin{array}{l}\text { Medidas para Proteção da } \\
\text { Saúde das Plantas }\end{array}$ & $\begin{array}{l}\text { Castanha de caju fresca ou seca descascada, goiabas e mangas frescas } \\
\text { ou secas, castanhas brasileiras frescas ou secas, mamão papaia fresco, } \\
\text { nozes frescas ou secas descascadas e sem pele, maranta e outras raízes } \\
\text { e tubérculos similares, sementes, frutos e esporos para cultivo, uvas } \\
\text { frescas, partes de plantas para fins ornamentais. }\end{array}$ \\
\hline $\begin{array}{l}\text { Medidas para Proteção da } \\
\text { Vida Selvagem }\end{array}$ & $\begin{array}{l}\text { Produtos de origem animal, gorduras e óleos animais e vegetais, partes } \\
\text { de plantas para fins ornamentais, bulbos e tubérculos (exceto aqueles } \\
\text { destinados ao consumo humano), plantas vivas, flores ornamentais, } \\
\text { musgos e liquens ornamentais. }\end{array}$ \\
\hline $\begin{array}{l}\text { Medidas para Controle do Uso } \\
\text { de Drogas }\end{array}$ & $\begin{array}{l}\text { Seivas e extratos vegetais, plantas, partes de plantas, sementes e frutos } \\
\text { usados em perfumaria, medicamentos ou inseticidas, fungicidas ou } \\
\text { propósitos similares. }\end{array}$ \\
\hline Medidas Gerais & $\begin{array}{l}\text { Seivas e extratos vegetais, plantas, partes de plantas, sementes e frutos } \\
\text { usados em perfumaria, medicamentos ou inseticidas, fungicidas ou } \\
\text { propósitos similares, bebidas alcoólicas (cerveja de malte, rum, } \\
\text { licores, vermute vodca, vinhos de uva, bebidas destiladas de uva), } \\
\text { bebidas não-alcoólicas. }\end{array}$ \\
\hline
\end{tabular}

Quadro 5 - Principais produtos afetados, em termos de valor exportado pelo Brasil, por barreiras não-tarifárias, nos Estados Unidos.

Fonte: Resultados da pesquisa.

A União Européia apresentou as seguintes barreiras não-tarifárias (Tabela 11):

- Medidas Antidumping.

- Medidas Compensatórias.

- Medidas para proteção do desenvolvimento:

○ quota para proteção do desenvolvimento

○ autorização para proteção do desenvolvimento

○ fiscalização prévia para proteção do desenvolvimento

- Medidas para controlar o uso de drogas:

○ autorização para controlar o uso de drogas 
- Medidas para proteção da vida selvagem:

○ autorização para proteção da vida selvagem

- Medidas para proteção da vida humana:

○ requerimentos de etiquetagem para proteção da saúde humana

○ fiscalização prévia para proteção da saúde humana

- requerimentos de características do produto para proteção da saúde humana

- Medidas gerais:

$\circ$ requerimentos de etiquetagem

○ licença não-automática

○ fiscalização prévia

- requerimentos técnicos

○ requerimentos de teste, inspeção ou quarentena

Com relação à União Européia, as medidas adotadas para proteção da vida selvagem, vida humana e medidas gerais foram as únicas que apresentaram relevância em termos de linhas tarifárias e valor afetados. Entretanto, a porcentagem de linhas tarifárias afetadas foi muito maior que a porcentagem do valor afetada, indicando a restrição dessas barreiras ao comércio ou ainda a pequena importância dos produtos afetados em termos de valor.

As medidas para proteção do desenvolvimento, medidas para controle do uso de drogas, direitos antidumping e direitos compensatórios apresentaram índices de freqüência e de cobertura iguais a zero, indicando que essas medidas não afetam os produtos da pauta de exportações agrícolas brasileiras para a União Européia.

As medidas autorização para controle do uso de drogas, taxas de compensação, licença não automática, requerimentos técnicos e requerimentos de teste, inspeção e quarentena, afetaram poucas linhas tarifárias e o índice de cobertura foi muito baixo, próximo ou igual a zero. Essas medidas podem estar restringindo o comércio ou o valor dos produtos afetados não tem grande relevância. 
Ainda, segundo a tabela 11, pode-se verificar que as únicas barreiras nãotarifárias que afetaram o valor exportado foram: autorização para proteção da vida selvagem e fiscalização prévia.

Tabela 11. Índice de frequiência e índice de cobertura para as BNTs sobre as exportações agrícolas brasileiras impostas pela União Européia em 2000.

\begin{tabular}{ccc}
\hline Barreira Não-Tarifária & 2000 & IC \\
\hline Medidas Antidumping & $0,00 \%$ & $0,00 \%$ \\
Medidas para Proteção do Desenvolvimento & $0,00 \%$ & $0,00 \%$ \\
Medidas para Controlar o Abuso de Drogas & $0,12 \%$ & $0,00 \%$ \\
Medidas para Proteção da Vida Selvagem & $21,61 \%$ & $7,23 \%$ \\
Medidas Compensatórias & $0,72 \%$ & $0,00 \%$ \\
Medidas para Proteção da Vida Humana & $7,68 \%$ & $0,02 \%$ \\
Medidas Gerais & $91,00 \%$ & $9,31 \%$ \\
Medidas de teste, inspeção e quarentena & $0,00 \%$ & $0,00 \%$ \\
\hline
\end{tabular}

Fonte: Cálculo com base em TRAINS e AliceWeb. 


\begin{tabular}{|c|c|}
\hline Barreira Não-Tarifária & Produtos \\
\hline Quotas Tarifárias & $\begin{array}{l}\text { Suco de laranja congelado, carne bovina desossada e congelada, } \\
\text { cortes e sobras comestíveis de carnes de aves congelados, carne } \\
\text { bovina desossada fresca ou resfriada, maçãs frescas, laranjas frescas } \\
\text { ou resfriadas, uvas frescas, carne suína congelada, aves inteiras } \\
\text { congeladas, açúcar de cana. }\end{array}$ \\
\hline Medidas Antidumping & - \\
\hline $\begin{array}{l}\text { Medidas para Proteção do } \\
\text { Desenvolvimento }\end{array}$ & - \\
\hline $\begin{array}{c}\text { Medidas para Controlar o Abuso } \\
\text { de Drogas }\end{array}$ & Sementes e frutos oleaginosos \\
\hline $\begin{array}{c}\text { Medidas para Proteção da Vida } \\
\text { Selvagem }\end{array}$ & $\begin{array}{l}\text { Carne bovina desossada e congelada, carne bovina desossada fresca } \\
\text { ou resfriada, carnes de cavalo, asnos, mulas, frescas, resfriadas ou } \\
\text { congeladas, produtos de origem animal inclusive animais mortos } \\
\text { inadequados para consumo humano, carne suína congelada, plantas } \\
\text { vivas, restos comestíveis de carne bovina congelados, cascos de } \\
\text { tartaruga, ossos de baleia. }\end{array}$ \\
\hline Direitos Compensatórios & - \\
\hline $\begin{array}{l}\text { Medidas para Proteção da Vida } \\
\text { Humana }\end{array}$ & $\begin{array}{l}\text { Bolachas doces, preparações alimentícias de cereais, macarrão, } \\
\text { cereais em grãos preparados. }\end{array}$ \\
\hline Medidas Gerais & $\begin{array}{l}\text { Carne bovina desossada e congelada, carne bovina ou restos } \\
\text { preparados ou em conserva, carne bovina desossada fresca ou } \\
\text { resfriada, resíduos vegetais de trigo para alimentação animal, açúcar } \\
\text { sólido de cana ou beterraba, bananas frescas ou secas (inclusive } \\
\text { mudas), frutas e castanhas congeladas ou em conserva. }\end{array}$ \\
\hline $\begin{array}{l}\text { Medidas de teste, inspeção e } \\
\text { quarentena }\end{array}$ & Bananas frescas ou secas (inclusive mudas) \\
\hline
\end{tabular}

Quadro 6 - Principais produtos afetados, em termos de valor exportado pelo Brasil, por barreiras não-tarifárias, na União Européia em 2000.

Fonte: Resultados da pesquisa.

Portanto, verifica-se o uso mais intenso das barreiras não-tarifárias por parte dos Estados Unidos. Além de imporem maior variedade de barreiras, a porcentagem do valor por elas afetada, excetuando-se o efeito das quotas tarifárias, é bem maior nos Estados Unidos do que a porcentagem desse valor afetada na União Européia.

Para verificar os produtos mais afetados, foram considerados os capítulos segundo o Sistema Harmonizado de Classificação e foram considerados os produtos sujeitos a pelo menos um tipo de barreira não-tarifária.

Com relação aos Estados Unidos (tabela 12):

Os capítulos plantas, raízes e tubérculos, preparações de carne e lã e pêlos apresentaram índice de cobertura e frequiência iguais a $100 \%$. Isso significa que todas as 
linhas tarifárias e todo o valor exportado estão sujeitos a algum tipo de barreira nãotarifária.

Os capítulos animais vivos, carnes, leite, laticínios e ovos, outros produtos de origem animal, plantas, raízes e tubérculos comestíveis, frutas, cereais, açúcares e confeitaria, preparações à base de cereais, etc., preparações de produtos de origem vegetal, preparações alimentícias diversas, bebidas alcoólicas e vinagres e produtos diversos das indústrias químicas apresentaram índice de cobertura de $100 \%$ e índice de freqüência menor do que $100 \%$. Isso significa que o valor dos produtos efetivamente exportado está sujeito a barreiras não-tarifárias e que as linhas tarifárias que não estão sujeitas a essas barreiras não são exportadas para esse parceiro comercial.

Os capítulos oleaginosos e matérias albuminóides apresentaram um índice de frequiência maior que o índice de cobertura. Isso pode indicar que as exportações estão sendo restringidas pelas barreiras ou que os produtos exportados que estão sujeitos a essas barreiras possuem um baixo valor em relação aos outros produtos do capítulo.

Os capítulos peleteria e algodão apresentaram índices de frequiência iguais a $100 \%$. Os índices de cobertura, em alguns casos também foram de $100 \%$ e em outros casos ficaram indeterminados. Nos casos em que os índices de cobertura são de 100\%, o valor das exportações desses produtos foi integralmente afetado por essas barreiras. Os casos em que o índice de cobertura ficou indeterminado foram aqueles em que as exportações totais do capítulo foram iguais a zero. Nesses casos, a barreira aplicada pode ter impedido o comércio desses produtos.

Os capítulos café, chá e especiarias e gorduras apresentaram índice de freqüência relativamente baixo e índice de cobertura igual a zero, indicando que poucas linhas tarifárias estão sujeitas a barreiras e que essas podem estar impedindo o comércio ou ainda, que essas linhas tarifárias afetadas são irrelevantes em termos de valor.

Os demais capítulos apresentaram índices de frequiência e cobertura iguais a $0 \%$. Isso significa que os produtos sujeitos a barreiras dentro desses capítulos não são aqueles exportados pelo Brasil para os Estados Unidos. Como nenhuma linha tarifária está sujeita a barreiras, a não exportação desses produtos não pode ser atribuída a qualquer tipo de restrição. 
Tabela 12. Índice de frequiência e índice de cobertura para barreiras não-tarifárias sobre as exportações agrícolas brasileiras impostas pelos Estados Unidos em 2000, por capítulo, segundo o sistema harmonizado.

\begin{tabular}{|c|c|c|c|}
\hline \multirow{2}{*}{ Capítulo } & \multirow{2}{*}{ Descrição } & \multicolumn{2}{|c|}{2000} \\
\hline & & IF & IC \\
\hline 01 & Animais vivos. & $71 \%$ & $100 \%$ \\
\hline 02 & Carnes. & $91 \%$ & $100 \%$ \\
\hline 04 & Leite, laticínios e ovos. & $93 \%$ & $100 \%$ \\
\hline 05 & Outros produtos de origem animal. & $70 \%$ & $100 \%$ \\
\hline 06 & Plantas vivas. & $100 \%$ & $100 \%$ \\
\hline 07 & Produtos hortícolas, raízes e tubérculos, comestíveis. & $94 \%$ & $100 \%$ \\
\hline 08 & Frutas. & $98 \%$ & $100 \%$ \\
\hline 09 & Café, chá e especiarias. & $13 \%$ & $0 \%$ \\
\hline 10 & Cereais. & $68 \%$ & $100 \%$ \\
\hline 11 & Produtos da indústria de moagem. & $0 \%$ & $0 \%$ \\
\hline 12 & Oleaginosos. & $38 \%$ & $70 \%$ \\
\hline 13 & Gomas, resinas. & $9 \%$ & $88 \%$ \\
\hline 14 & Matérias para entrançar. & $0 \%$ & $0 \%$ \\
\hline 15 & Gorduras. & $6 \%$ & $4 \%$ \\
\hline 16 & Preparações de carne. & $100 \%$ & $100 \%$ \\
\hline 17 & Açúcares, confeitaria. & $41 \%$ & $100 \%$ \\
\hline 18 & Cacau. & $0 \%$ & $0 \%$ \\
\hline 19 & Preparações à base de cereais, etc. & $82 \%$ & $100 \%$ \\
\hline 20 & Preparações de produtos de origem vegetal. & $92 \%$ & $100 \%$ \\
\hline 21 & Preparações alimentícias diversas. & $86 \%$ & $100 \%$ \\
\hline 22 & Bebidas alcoólicas e vinagres. & $74 \%$ & $96 \%$ \\
\hline 23 & Resíduos das indústrias alimentares. & $0 \%$ & $0 \%$ \\
\hline 24 & Fumo (tabaco). & $0 \%$ & $0 \%$ \\
\hline 29 & Produtos químicos orgânicos. & $0 \%$ & $0 \%$ \\
\hline 33 & Óleos essenciais e resinóides. & $0 \%$ & $0 \%$ \\
\hline 35 & Matérias albuminóides. & $6 \%$ & $0 \%$ \\
\hline 38 & Produtos diversos das indústrias químicas. & $0 \%$ & $0 \%$ \\
\hline 41 & Peles e couros. & $71 \%$ & $100 \%$ \\
\hline 43 & Peleteria. & $100 \%$ & $100 \%$ \\
\hline 50 & Seda. & $0 \%$ & $\mathrm{n} / \mathrm{a}$ \\
\hline 51 & Lã e pêlos. & $100 \%$ & $100 \%$ \\
\hline 52 & Algodão. & $100 \%$ & $\mathrm{n} / \mathrm{a}$ \\
\hline 53 & Fios de papel. & $0 \%$ & $\mathrm{n} / \mathrm{a}$ \\
\hline
\end{tabular}

Fonte: Cálculo com base em TRAINS e AliceWeb.

Com relação à União Européia (Tabela 13), o capítulo peleteria apresentou índices de cobertura e frequiência iguais a 100\%. Isso significa que todas as linhas tarifárias e todo o valor exportado estão sujeitos a algum tipo de barreira não-tarifária.

Os capítulos outros produtos de origem animal, cereais e peles e couros apresentaram índices de cobertura iguais a 100\% e índices de freqüência menores do que 
$100 \%$. Isso significa que o valor dos produtos efetivamente exportados está sujeito a barreiras não-tarifárias e que as linhas tarifárias que não estão sujeitas a essas barreiras não são exportadas para esse parceiro comercial.

Os capítulos animais vivos, açúcares e confeitaria, preparações à base de cereais, etc. apresentaram índices de frequiência e cobertura muito altos, indicando uma alta proteção nesses capítulos. Entretanto, algumas linhas tarifárias exportadas pelo Brasil não se encontram sujeitas a barreiras não-tarifárias. Essa conclusão deve-se ao fato de o índice de cobertura ser diferente de $100 \%$.

Os capítulos carnes, leite, laticínios e ovos, plantas vivas, resíduos das indústrias alimentares, preparações alimentícias diversas apresentaram índice de frequiência bem maior que o índice de cobertura. Isso pode indicar que as exportações estão sendo restringidas pelas barreiras ou que o valor de comércio desses produtos é pouco relevante em relação à pauta de exportações agrícolas brasileiras.

Os capítulos plantas, raízes e tubérculos comestíveis e preparações de carne apresentaram índices de frequiência baixos e índices de cobertura muito altos, ou seja, esses capítulos apresentam poucas linhas tarifárias protegidas por barreiras não-tarifárias, entretanto estas coincidem com as que estão sendo exportadas pelo Brasil.

Os capítulos frutas, oleaginosos, gomas, resinas, matérias para entrançar, gorduras, preparações de produtos de origem vegetal, bebidas alcoólicas e vinagres, lã e pêlos apresentaram baixa proteção através de barreiras não-tarifárias nesse mercado, refletida nos baixos índices de freqüência e cobertura apresentados.

Os capítulos leite, laticínios e ovos, plantas, raízes e tubérculos comestíveis, gomas, resinas, preparações de carne, açúcares e confeitaria, preparações à base de cereais, etc. apresentaram índice de frequiência menor que o índice de cobertura. Isso indica que poucas linhas tarifárias foram afetadas pelas barreiras, entretanto o valor das exportações dessas linhas é bastante significativo dentro do capítulo.

Os demais capítulos apresentaram índices de frequiência e cobertura iguais a $0 \%$. Isso significa que os produtos sujeitos a barreiras dentro desses capítulos não são aqueles exportados pelo Brasil para a União Européia. Como nenhuma linha tarifária está sujeita 
barreiras, a não exportação desses produtos não pode ser atribuída a qualquer tipo de restrição.

Tabela 13. Índice de freqüência e índice de cobertura para barreiras não-tarifárias sobre as exportações agrícolas brasileiras impostas pela União Européia em 2000, por capítulo segundo o sistema harmonizado.

\begin{tabular}{|c|c|c|c|}
\hline \multirow{2}{*}{ Capítulo } & \multirow{2}{*}{ Descrição } & \multicolumn{2}{|c|}{2000} \\
\hline & & IF & IC \\
\hline 01 & Animais vivos. & $48 \%$ & $91 \%$ \\
\hline 02 & Carnes. & $71 \%$ & $66 \%$ \\
\hline 04 & Leite, laticínios e ovos. & $84 \%$ & $14 \%$ \\
\hline 05 & Outros produtos de origem animal. & $39 \%$ & $100 \%$ \\
\hline 06 & Plantas vivas. & $69 \%$ & $67 \%$ \\
\hline 07 & Plantas, raízes e tubérculos comestíveis. & $13 \%$ & $88 \%$ \\
\hline 08 & Frutas. & $19 \%$ & $5 \%$ \\
\hline 09 & Café, chá e especiarias. & $0 \%$ & $0 \%$ \\
\hline 10 & Cereais. & $89 \%$ & $100 \%$ \\
\hline 11 & Produtos da indústria de moagem. & $79 \%$ & $26 \%$ \\
\hline 12 & Oleaginosos. & $5 \%$ & $0 \%$ \\
\hline 13 & Gomas, resinas. & $9 \%$ & $8 \%$ \\
\hline 14 & Matérias para entrançar. & $13 \%$ & $8 \%$ \\
\hline 15 & Gorduras. & $15 \%$ & $5 \%$ \\
\hline 16 & Preparações de carne. & $18 \%$ & $90 \%$ \\
\hline 17 & Açúcares, confeitaria. & $77 \%$ & $66 \%$ \\
\hline 18 & Cacau. & $0 \%$ & $0 \%$ \\
\hline 19 & Preparações à base de cereais, etc. & $64 \%$ & $89 \%$ \\
\hline 20 & Preparações de produtos de origem vegetal. & $18 \%$ & $0 \%$ \\
\hline 21 & Preparações alimentícias diversas. & $25 \%$ & $3 \%$ \\
\hline 22 & Bebidas alcoólicas e vinagres. & $19 \%$ & $1 \%$ \\
\hline 23 & Resíduos das indústrias alimentares. & $70 \%$ & $3 \%$ \\
\hline 24 & Fumo (tabaco). & $0 \%$ & $0 \%$ \\
\hline 29 & Produtos químicos orgânicos. & $0 \%$ & $0 \%$ \\
\hline 33 & Óleos essenciais e resinóides. & $0 \%$ & $0 \%$ \\
\hline 35 & Matérias albuminóides. & $0 \%$ & $0 \%$ \\
\hline 38 & Produtos diversos das indústrias químicas. & $0 \%$ & $0 \%$ \\
\hline 41 & Peles e couros. & $71 \%$ & $100 \%$ \\
\hline 43 & Peleteria. & $100 \%$ & $100 \%$ \\
\hline 50 & Seda. & $0 \%$ & $0 \%$ \\
\hline 51 & Lã e pêlos. & $11 \%$ & $0 \%$ \\
\hline 52 & Algodão. & $0 \%$ & $0 \%$ \\
\hline 53 & Fios de papel. & $0 \%$ & $0 \%$ \\
\hline
\end{tabular}

Fonte: Cálculo com base em TRAINS e AliceWeb. 
A tabela 14 mostra quais capítulos estão sujeitos a picos tarifários e barreiras nãotarifárias nos Estados Unidos e na União Européia. Para tanto, foram considerados os índices de freqüência como indicadores da intenção de proteção por parte desses parceiros comerciais. A presença de tais barreiras foi considerada quando o índice de frequiência foi diferente de zero.

Observa-se que a grande maioria dos capítulos apresenta algum tipo de restrição nos Estados Unidos ou na União Européia. Alguns produtos apresentam picos tarifários e barreiras tarifárias em ambos os parceiros como: carnes, leite, laticínios e ovos, produtos hortícolas, raízes e tubérculos comestíveis, frutas, gorduras, açúcares e confeitaria, preparações à base de cereais, etc., preparações de produtos de origem vegetal, preparações alimentícias diversas, bebidas alcoólicas e vinagres. 
Tabela 14. Presença de picos tarifários e barreiras não-tarifárias sobre as exportações agrícolas brasileiras, por capítulos, nos Estados Unidos e União Européia em 2000 .

\begin{tabular}{|c|c|c|c|c|c|}
\hline \multirow{2}{*}{ Capítulos } & \multirow{2}{*}{ Descrição } & \multicolumn{2}{|c|}{ EUA } & \multicolumn{2}{|c|}{$\mathrm{UE}$} \\
\hline & & $\mathrm{BT}$ & BNT & $\mathrm{BT}$ & BNT \\
\hline 01 & Animais vivos. & & $\mathrm{x}$ & $\mathrm{x}$ & $\mathrm{x}$ \\
\hline 02 & Carnes. & $\mathrm{x}$ & $\mathrm{x}$ & $\mathrm{x}$ & $\mathrm{x}$ \\
\hline 04 & Leite, laticínios e ovos. & $\mathrm{x}$ & $\mathrm{x}$ & $\mathrm{x}$ & $\mathrm{x}$ \\
\hline 05 & Outros produtos de origem animal. & & $\mathrm{x}$ & & $\mathrm{x}$ \\
\hline 06 & Plantas vivas. & & $\mathrm{x}$ & & $\mathrm{x}$ \\
\hline 07 & Plantas, raízes e tubérculos comestíveis. & $\mathrm{x}$ & $\mathrm{x}$ & $\mathrm{x}$ & $\mathrm{x}$ \\
\hline 08 & Frutas. & $\mathrm{x}$ & $\mathrm{x}$ & $\mathrm{x}$ & $\mathrm{x}$ \\
\hline 09 & Café, chá e especiarias. & & $\mathrm{x}$ & & \\
\hline 10 & Cereais. & & $\mathrm{x}$ & $\mathrm{x}$ & $\mathrm{x}$ \\
\hline 11 & Produtos da indústria de moagem. & & & $\mathrm{x}$ & $\mathrm{x}$ \\
\hline 12 & Oleaginosos. & $\mathrm{x}$ & $\mathrm{x}$ & & $\mathrm{x}$ \\
\hline 13 & Gomas, resinas. & & $\mathrm{x}$ & $\mathrm{x}$ & $\mathrm{x}$ \\
\hline 14 & Matérias para entrançar. & & & & $\mathrm{x}$ \\
\hline 15 & Gorduras. & $\mathrm{x}$ & $\mathrm{x}$ & $\mathrm{x}$ & $\mathrm{x}$ \\
\hline 16 & Preparações de carne. & & $\mathrm{x}$ & $\mathrm{x}$ & $\mathrm{x}$ \\
\hline 17 & Açúcares, confeitaria. & $\mathrm{x}$ & $\mathrm{x}$ & $\mathrm{x}$ & $\mathrm{x}$ \\
\hline 18 & Cacau. & $\mathrm{x}$ & & $\mathrm{x}$ & \\
\hline 19 & Preparações à base de cereais, etc. & $\mathrm{x}$ & $\mathrm{x}$ & $\mathrm{x}$ & $\mathrm{x}$ \\
\hline 20 & Preparações de produtos de origem vegetal. & $\mathrm{x}$ & $\mathrm{x}$ & $\mathrm{x}$ & $\mathrm{x}$ \\
\hline 21 & Preparações alimentícias diversas. & $\mathrm{x}$ & $\mathrm{x}$ & $\mathrm{x}$ & $\mathrm{x}$ \\
\hline 22 & Bebidas alcoólicas e vinagres. & $\mathrm{x}$ & $\mathrm{x}$ & $\mathrm{x}$ & $\mathrm{x}$ \\
\hline 23 & Resíduos das indústrias alimentares. & $\mathrm{x}$ & & $\mathrm{x}$ & $\mathrm{x}$ \\
\hline 24 & Fumo (tabaco). & $\mathrm{x}$ & & $\mathrm{x}$ & \\
\hline 29 & Produtos químicos orgânicos. & & & $\mathrm{x}$ & \\
\hline 33 & Óleos essenciais e resinóides. & & & & \\
\hline 35 & Matérias albuminóides. & & $\mathrm{x}$ & $\mathrm{x}$ & \\
\hline 38 & Produtos diversos das indústrias químicas. & & & & \\
\hline 41 & Peles e couros. & & $\mathrm{x}$ & & $\mathrm{x}$ \\
\hline 43 & Peleteria. & & $\mathrm{x}$ & & $\mathrm{x}$ \\
\hline 50 & Seda. & & & & \\
\hline 51 & Lã e pêlos. & & $\mathrm{x}$ & & $\mathrm{x}$ \\
\hline 52 & Algodão. & $\mathrm{x}$ & $\mathrm{x}$ & & \\
\hline 53 & Fios de papel. & & & & \\
\hline
\end{tabular}

Fonte: Resultados da pesquisa. 


\section{CONCLUSÕES}

Os produtos agrícolas são altamente protegidos nos Estados Unidos e na União Européia. Praticamente todos os capítulos que incluem esses produtos apresentam algum tipo de restrição nesses mercados.

Com relação a barreiras tarifárias, a média e mediana de tarifas apresentadas pela União Européia foram maiores que as médias e medianas apresentadas pelos Estados Unidos. Isso demonstra a utilização de tarifas mais elevadas, incidindo sobre um maior número de linhas tarifárias por parte da União Européia.

A União Européia apresentou, também, um maior número de linhas tarifárias sujeitas a picos tarifários do que os Estados Unidos. Entretanto, em termos de valor exportado pelo Brasil, a porcentagem sujeita a esse tipo de restrição foi maior nos Estados Unidos. Esse fato sugere duas conclusões: os picos tarifários foram mais restritivos na União Européia ou afetaram produtos de menor valor exportado pelo Brasil para esse mercado, ou seja, produtos menos relevantes.

Alguns dos produtos relevantes, em termos de valor, para a pauta de exportações agrícolas do Brasil, mais afetados por picos tarifários nos Estados Unidos foram tabaco, suco de laranja, açúcar, chocolate e outras preparações contendo cacau. Na União Européia, foram carne bovina, suco de laranja, tabaco, banana, açúcar, carne suína e álcool.

Com relação a barreiras não-tarifárias, de modo geral, o valor afetado por essas medidas foi maior nos Estados Unidos do que na União Européia. A partir daí pode-se chegar às seguintes conclusões: as BNTs são mais restritivas na União Européia, impedindo ou restringindo a exportação desse produtos por esse parceiro, diminuindo o 
valor exportado, ou os produtos sujeitos a essas barreiras são menos relevantes em termos de valor nesse mercado.

Os Estados Unidos utilizaram mais amplamente quotas tarifárias, entretanto a parcela da pauta afetada foi maior na União Européia.

Alguns produtos, relevantes em termos de valor na pauta de exportações do Brasil, cujas exportações foram sujeitas a quotas tarifárias nos Estados Unidos, foram tabaco, açúcar de cana, chocolate, preparações alimentícias e na União Européia, foram suco de laranja congelado, carne bovina, suína e de aves e algumas frutas frescas.

Com relação a outras barreiras não-tarifárias, nos Estados Unidos, as medidas para proteção da saúde humana e medidas para proteção da saúde das plantas foram as que incidiram sobre o maior número de linhas tarifárias e também sobre parcela significativa do valor exportado, porém o coeficiente de cobertura foi bem mais baixo do que o de frequiência, o que pode indicar restrição no comércio dos produtos agrícolas ou pouca relevância do valor correspondente aos produtos sobre os quais incidiram. Quando analisados os capítulos separadamente, pôde-se verificar elevada proteção através de barreiras não-tarifárias para a maioria dos capítulos.

A União Européia utiliza-se de um menor número de barreiras não tarifárias, entretanto a medida requerimentos gerais foi observada incidindo sobre $91 \%$ das linhas tarifárias. O coeficiente de cobertura dessa medida foi bem mais baixo $(9,31 \%)$, podendo levar à conclusão de que essa medida restringe amplamente o comércio entre Brasil e União Européia. Vários capítulos apresentaram altos índices de cobertura e frequiência para barreiras não-tarifárias.

Considerando os produtos de valor relevante dentro da pauta de exportações brasileiras, as barreiras sanitárias e fitossanitárias incidiram sobre um maior número de produtos em ambos os parceiros comerciais. Nos Estados Unidos, os principais produtos de valor relevante sujeitos a barreiras sanitárias e fitossanitárias foram: carnes e produtos de origem animal, sucos de frutas frescos, suco de laranja congelado, frutas e castanhas frescas ou secas, plantas ou partes de plantas voltadas ao cultivo ou para uso ornamental. Na União Européia, dentre as barreiras não-tarifárias apresentadas, a grande maioria referiu-se a barreiras sanitárias e fitossanitárias e incidiram principalmente sobre 
produtos como carnes e produtos de origem animal, bananas, bolachas doces, macarrão e cereais para alimentação humana.

Medidas Antidumping e Direitos Compensatórios incidiram sobre suco de laranja e óleo de rícino dentre os produtos elevantes em termos de valor, exportados para os Estados Unidos e não incidiram sobre nenhum produto exportado pelo Brasil para a União Européia.

Comparando Estados Unidos e União Européia verificou-se, através da análise dos índices de frequiência, que a União Européia utiliza mais amplamente medidas tarifárias, enquanto que os Estados Unidos utilizam mais amplamente medidas nãotarifárias. Entre as medidas não-tarifárias, os Estados Unidos apresentaram mais linhas tarifárias sujeitas a quotas tarifárias e a medidas sanitárias e fitossanitárias e a União Européia apresentou maior número de linhas tarifárias sujeitas a barreiras técnicas.

Com relação aos valores afetados, os Estados Unidos apresentaram índices de coberturas maiores para picos tarifários e barreiras não-tarifárias em geral e a União Européia apresentou maior índice de cobertura para quotas tarifárias. Esses resultados podem levar a duas conclusões:

a. os picos tarifários e as medidas não-tarifárias estão reduzindo o valor das exportações dos produtos agrícolas do Brasil para a União Européia e as quotas tarifárias estão reduzindo o valor das exportações do Brasil para os Estados Unidos, ou seja, essas medidas estão sendo efetivas como forma de proteção ou protecionismo nesses países

b. os picos tarifários e as medidas não-tarifárias estão incidindo sobre produtos de valor pouco relevante em relação às exportações agrícolas do Brasil para a União Européia e as quotas tarifárias estão incidindo sobre produtos de valor pouco relevante em relação às exportações agrícolas do Brasil para os Estados Unidos.

Os resultados não foram muito conclusivos no sentido de estabelecer os produtos cujas exportações estão sendo mais restringidas por medidas de proteção e 
protecionismo, já que apresentaram alguns resultados ambíguos, decorrentes da presença de variáveis que não foram estudadas neste trabalho e que também podem estar limitando essas exportações. Entretanto, o trabalho permitiu verificar os principais produtos que foram atingidos por cada medida e verificar a estrutura de proteção dos Estados Unidos e da União Européia, com relação aos produtos agrícolas brasileiros.

As bases utilizadas neste trabalho apresentam várias limitações, fazendo com que ocorram divergências dos resultados. Em primeiro lugar, a ausência de uma nomenclatura comum para todos os produtos acima de seis dgitos dificulta o cruzamento dos dados. Para possibilitar o trabalho, as barreiras que incidiram sobre produtos a 8 ou 10 dígitos foram agregadas em linhas tarifárias a 6 dígitos, para permitir uma uniformidade dos dados. Esse procedimento pode ter superestimado o valor e número de linhas tarifárias afetadas.

Todas as bases apresentaram poucos anos disponíveis e não deixam claro o momento exato em que as medidas são impostas.

A comparação entre as bases foi divergente. No caso da comparação entre a AMAD e o TRAINS houve grande divergência entre os produtos e valores que estavam sendo afetados por quotas tarifárias; no caso do TRAINS e ALICE houve divergências entre os valores exportados pelo Brasil para Estados Unidos e União Européia.

A base de dados do TRAINS não distingue as medidas não-tarifárias de barreiras não-tarifárias, ou seja, não esclarece se as medidas são legítimas ou não.

A BDH apresenta dados apenas para os países das Américas, não permitindo uma comparação entre esses países e os países de outros continentes.

Para novos estudos, ficam as seguintes sugestões: avaliação da efetividade da aplicação de barreiras comerciais, através da verificação da alteração na dinâmica das exportações no momento da imposição das medidas; uso de modelos econométricos para definir o impacto de uma ou mais barreiras, na exportação de um produto ou grupo de produtos.

Outra sugestão seria a de se estudar cada capítulo individualmente ou complexos para que haja um maior detalhamento dos produtos sensíveis, já que neste trabalho isso não foi possível, devido à grande abrangência de produtos. 
ANEXO:

Algumas categorias de barreiras não-tarifárias presentes no comércio internacional 


\section{ANEXO - Algumas categorias de barreiras não-tarifárias presentes no comércio internacional.}

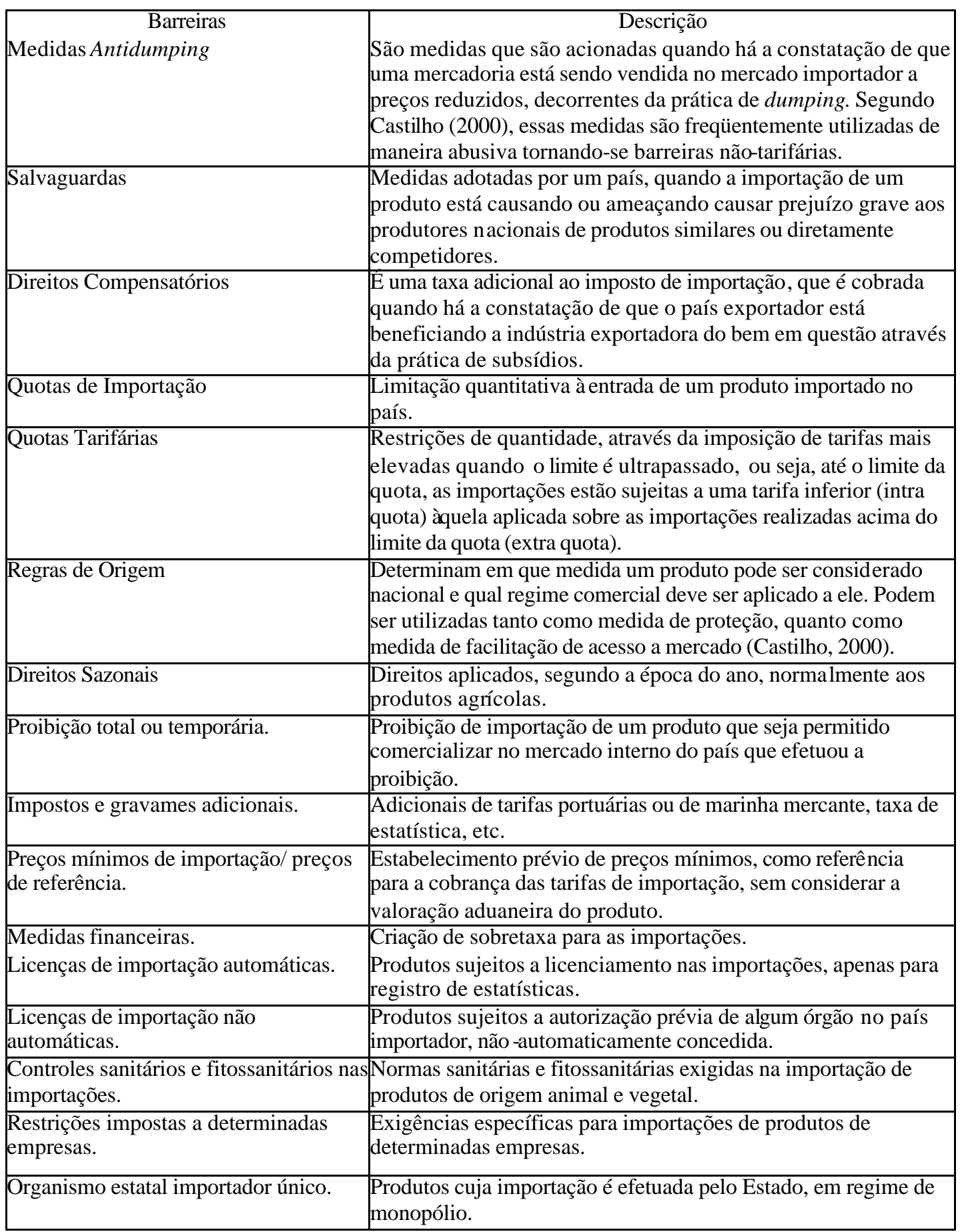




\section{ANEXO - Algumas categorias de barreiras não-tarifárias presentes no comércio internacional.}

\begin{tabular}{|c|c|}
\hline \begin{tabular}{|c|} 
Barreira \\
Serviços nacionais obrigatórios.
\end{tabular} & Direitos consulares. \\
\hline $\begin{array}{l}\text { Requisitos relativos às características } \\
\text { dos produtos. }\end{array}$ & Produtos sujeitos à avaliação de conformidade. \\
\hline Requisitos relativos à embala gem. & $\begin{array}{l}\text { Exigências de materiais, tamanhos ou padrões de peso para } \\
\text { embalagens de produtos. }\end{array}$ \\
\hline Requisitos relativos à rotulagem. & $\begin{array}{l}\text { Exigências especiais quanto a tipo, tamanho de letras ou } \\
\text { tradução nos rótulos de produtos. }\end{array}$ \\
\hline $\begin{array}{l}\text { Requisitos relativos a informações } \\
\text { sobre o produto. }\end{array}$ & $\begin{array}{l}\text { Exigências de conteúdo alimentar ou protéico de produtos ou de } \\
\text { informações ao consumidor. }\end{array}$ \\
\hline $\begin{array}{l}\text { Requisitos relativos à inspeção, ensaios } \\
\text { e quarentena. }\end{array}$ & $\begin{array}{l}\text { Produtos sujeitos à inspeção física e análise nas alfândegas ou a } \\
\text { procedimentos de quarentena. }\end{array}$ \\
\hline Outros requisitos técnicos. & $\begin{array}{l}\text { Exigência de certificados relativos à fabricação do produto } \\
\text { mediante processos não poluidores do meio ambiente. }\end{array}$ \\
\hline Inspeção prévia àimportação. & Inspeção pré-embarque. \\
\hline Procedimentos aduaneiros especiais. & $\begin{array}{l}\text { Exigência de ingresso de importações somente por determinados } \\
\text { portos ou aeroportos. }\end{array}$ \\
\hline $\begin{array}{l}\text { Exigência de conteúdo } \\
\text { nacional/regional. }\end{array}$ & $\begin{array}{l}\text { Discriminação de importações para favorecer as que tenham } \\
\text { matéria-prima originária do país importador. }\end{array}$ \\
\hline Exigência de intercâmbio compensado. & $\begin{array}{l}\text { Condicionamento de importações à exportação casada de } \\
\text { determinados produtos. }\end{array}$ \\
\hline $\begin{array}{l}\text { Exigências especiais para compras } \\
\text { governamentais. }\end{array}$ & $\begin{array}{l}\text { Tratamento favorecido aos produtos nacionais em concorrências } \\
\text { públicas. }\end{array}$ \\
\hline
\end{tabular}

Fontes: Brasil (2001); Castilho (2000) 


\section{REFERÊNCIAS BIBLIOGRÁFICAS}

BEGHIN, J.C.; BUREAU, J.C. Measurement of sanitary and technical barriers to trade. Ames: Iowa State University, Department of Economics, Center for Agricultural and Rural Development, 2001. 21p. (Scoping paper prepared for the OECD Agricultural Food and Fisheries Directorate)

CARVALHO, M.A.; SILVA, C.R.L. Economia internacional. São Paulo: Saraiva, 2000. 300p.

CASTILHO, M.R. Uma investigação sobre as barreiras não-tarifárias impostas às importações brasileiras. Revista Brasileira de Comércio Exterior, n.47, p.51-60, jan/mar. 1996.

CASTILHO, M.R. O sistema de preferências comerciais da União Européia. Rio de Janeiro: IPEA, 2000. 62p. (Texto para discussão, 742)

deGORTER, H.; ABBOTT, P.; BARICHELlO, R. et. al. Agriculture in the WTO: issues in reforming tariff-rate import quotas in the agreement on agriculture in the WTO. St. Paul: University of Minnesota, Department of Applied Economics, International Agricultural Trade Research Consortium, 2001. 188p. (Commissioned Paper, 13)

FAGUNDES, M.H. (Coord.). Políticas agrícolas e o comércio mundial. Rio de Janeiro: IPEA, 1994. 466p. (Estudos de Política Agrícola, 28) 
GIBSON, P.; WAINIO, J.; WHITLEY, D.; BOHMAN, M. Profiles of tariffs in global agricultural markets. Washington: U.S. Department of Agriculture, Economic Research Service, Market and Trade Economics Division, Jan. 2001, 52p. (Agricultural Economic Report, 796)

JANK, M.S.; NASSAR, A.M. Competitividade e globalização. In: ZYLBERSZTAJN, D.; NEVES, M.F. (Org.). Economia e gestão dos negócios agroalimentares. São Paulo: Pioneira, 2000. cap.7, p.137-163.

JANK, M.S.; VIEGAS, I.F.P. A OMC e o agronegócio: o desafio da rodada do milênio. Preços Agrícolas, v.14, n.156, p.3-10, out.1999.

KRUGMAN, P.R.; OBSTFELD, M. Economia internacional: teoria e política. 4.ed. São Paulo: Makron Books, 1999. 807p.

LAIRD, S. Quantifying commercial policies. Stanford: Stanford University, Institute for Theoretical Economics, 1996. 43p. (World Trade Organization, Staff Working Paper)

LAIRD, S. Multilateral approaches to market access negotiations. Genebra: WTO, 1998. 23p. (World Trade Organization, Staff Working Paper)

BRASIL. Ministério do Desenvolvimento, Indústria e Comércio Exterior. Barreiras técnicas às exportações brasileiras 1999. Brasília, out. 1999. 86p.

BRASIL. Ministério do Desenvolvimento, Indústria e Comércio Exterior. Barreiras técnicas às exportações brasileiras 2001. Brasília, 2001. 87p.

ORGANIZAÇÃO MUNDIAL DE COMÉRCIO. Agriculture, trade and the GATT: a glossary of terms. http://www.wto.org (23 Dec. 2002)

PEREIRA, L.V. Indicadores de incidência das barreiras não-tarifárias praticadas pelos países desenvolvidos contra as exportações brasileiras. Rio de Janeiro: IPEA, 1989. 68p. (Texto para Discussão Interna, 22)

PINAZZA, L.A.; ALIMANDRO, R. Reconhecer não basta. Agroanalysis, v.21, n.10, p.57-58, out. 2001. 
THORSTENSEN, V. Organização Mundial do Comércio: as regras do comércio internacional e a rodada do milênio. São Paulo: Edições Aduaneiras, 1999. 517p.

UNITED NATIONS CONFERENCE ON TRADE AND DEVELOPMENT; WORLD TRADE ORGANIZATION. The post-Uruguay round tariff environment for developing countries exports, tariff peaks and tariff escalation. Geneva, 2000. $23 p$. 
APÊNDICE:

Descrição de seções e capítulos do agribusiness 
APÊNDICE - Descrição de seções e capítulos do agribusiness.

\begin{tabular}{|c|c|}
\hline $\begin{array}{l}\text { Seções e } \\
\text { Capítulos }\end{array}$ & Descrição \\
\hline SEÇÃO I & ANIMAIS VIVOS E PRODUTOS DO REINO ANIMAL \\
\hline \multicolumn{2}{|l|}{ Capítulos } \\
\hline 01 & Animais vivos. \\
\hline 02 & Carnes e miudezas, comestíveis. \\
\hline 04 & $\begin{array}{l}\text { Leite e laticínios; ovos de aves; mel natural; produtos comestíveis de origem animal, não } \\
\text { especificados nem compreendidos em outros Capítulos. }\end{array}$ \\
\hline 05 & $\begin{array}{l}\text { Outros produtos de origem animal, não especificados nem compreendidos em outros } \\
\text { Capítulos. }\end{array}$ \\
\hline SEÇÃO II & PRODUTOS DO REINO VEGETAL \\
\hline \multicolumn{2}{|l|}{ Capítulos } \\
\hline 06 & Plantas vivas e produtos de floricultura. \\
\hline 07 & Produtos hortícolas, plantas, raízes e tubérculos, comestíveis. \\
\hline 08 & Frutas; cascas de cítricos e de melões. \\
\hline 09 & Café, chá, mate e especiarias. \\
\hline 10 & Cereais. \\
\hline 11 & Produtos da indústria de moagem; malte; amidos e féculas; inulina; glúten de trigo. \\
\hline 12 & $\begin{array}{l}\text { Sementes e frutos oleaginosos; grãos, sementes e frutos diversos; plantas industriais ou } \\
\text { medicinais; palha e forragem. }\end{array}$ \\
\hline 13 & Gomas, resinas e outros sucos e extratos vegetais. \\
\hline 14 & $\begin{array}{l}\text { Matérias para entrançar e outros produtos de origem vegetal, não especificados nem } \\
\text { compreendidos em outros Capítulos. }\end{array}$ \\
\hline $\begin{array}{l}\text { SEÇÃO } \\
\text { III }\end{array}$ & $\begin{array}{l}\text { GORDURAS E ÓLEOS ANIMAIS OU VEGETAIS; PRODUTOS DA SUA } \\
\text { DISSOCIAÇÃO; GORDURAS ALIMENTARES ELABORADAS; CERAS DE ORIGEM } \\
\text { ANIMAL OU VEGETAL. }\end{array}$ \\
\hline \multicolumn{2}{|l|}{ Capítulo } \\
\hline 15 & $\begin{array}{l}\text { Gorduras e óleos animais ou vegetais; produtos da sua dissociação; gorduras alimentares } \\
\text { elaboradas; ceras de origem animal ou vegetal. }\end{array}$ \\
\hline
\end{tabular}


APÊNDICE - Descrição de seções e capítulos do agribusiness.

\begin{tabular}{|c|c|}
\hline $\begin{array}{l}\text { Seções e } \\
\text { Capítulos }\end{array}$ & Descrição \\
\hline $\begin{array}{l}\text { SEÇÃO } \\
\text { IV }\end{array}$ & $\begin{array}{l}\text { PRODUTOS DAS INDÚSTRIAS ALIMENTARES; BEBIDAS, LÍQUIDOS ALCOÓLICOS } \\
\text { E VINAGRES; FUMO (TABACO) E SEUS SUCEDÂNEOS MANUFATURADOS. }\end{array}$ \\
\hline \multicolumn{2}{|l|}{ Capítulos } \\
\hline 16 & $\begin{array}{l}\text { Preparações de carne, de peixes ou de crustáceos, de moluscos ou de outros invertebrados } \\
\text { aquáticos. }\end{array}$ \\
\hline 17 & Açúcares e produtos de confeitaria. \\
\hline 18 & Cacau e suas preparações. \\
\hline 19 & Preparações à base de cereais, farinhas, amidos, féculas ou de leite; produtos de pastelaria. \\
\hline 20 & Preparações de produtos hortícolas, de frutas ou de outras partes de plantas. \\
\hline 21 & Preparações alimentícias diversas. \\
\hline 22 & Bebidas, líquidos alcoólicos e vinagres. \\
\hline 23 & Resíduos e desperdícios das indústrias alimentares; alimentos preparados para animais. \\
\hline 24 & Fumo (tabaco) e seus sucedâneos, manufaturados. \\
\hline $\begin{array}{l}\text { SEÇÃO } \\
\text { VI }\end{array}$ & PRODUTOS DAS INDÚSTRIAS QUIIMICAS OU DAS INDÚSTRIAS CONEXAS \\
\hline \multicolumn{2}{|l|}{ Capítulos } \\
\hline 29 & Produtos químicos orgânicos. \\
\hline 33 & $\begin{array}{l}\text { Óleos essenciais e resinóides; produtos de perfumaria ou de toucador preparados e } \\
\text { preparações cosméticas. }\end{array}$ \\
\hline 35 & Matérias albuminóides; produtos àbase de amidos ou de féculas modificados; colas; enzimas. \\
\hline 38 & Produtos diversos das indústrias químicas. \\
\hline $\begin{array}{l}\text { SEÇÃO } \\
\text { VIII }\end{array}$ & $\begin{array}{l}\text { PELES, COUROS, PELETERIA (PELES COM PÊLO*) E OBRAS DESTAS MATÉRIAS; } \\
\text { ARTIGOS DE CORREEIRO OU DE SELEIRO; ARTIGOS DE VIAGEM, BOLSAS E } \\
\text { ARTEFATOS SEMELHANTES; OBRAS DE TRIPA }\end{array}$ \\
\hline \multicolumn{2}{|l|}{ Capítulos } \\
\hline 41 & Peles, exceto a peleteria (peles com pêlo), e couros. \\
\hline
\end{tabular}


APÊNDICE - Descrição de seções e capítulos do agribusiness.

\begin{tabular}{|c|l|}
\hline $\begin{array}{c}\text { Seções e } \\
\text { Capítulos }\end{array}$ & \multicolumn{1}{c|}{ Descrição } \\
\hline 43 & Peleteria (peles com pêlo) e suas obras; peleteria (peles com pêlo) artificial. \\
\hline $\begin{array}{c}\text { SEÇÃO } \\
\text { XI }\end{array}$ & MATÉRIAS TÊXTEIS E SUAS OBRAS \\
\hline Capítulos & \\
\hline 50 & Seda. \\
\hline 51 & Lã e pêlos finos ou grosseiros; fios e tecidos de crina. \\
\hline 52 & Algodão. \\
\hline 53 & Outras fibras têxteis vegetais; fios de papel e tecido de fios de papel. \\
\hline
\end{tabular}

Fonte: Brasil (2001) 